\title{
LOS CABILDOS CATEDRALICIOS DE SANTIAGO Y ORENSE EN EL REINADO DE FELIPE V: ALGUNOS RESULTADOS*
}

\section{The Chapters of the Cathedrals of Santiago de Compostela and Ourense during the Reign of King Philip V: Preliminary Results}

\section{María SEIJAS MONTERO}

Universidad de Vigo

Correo-e: mariaseijas@uvigo.es

Laura RODICIO PEREIRA

Universidad de Vigo

Correo-e: 1rodicio@uvigo.es

RESUMEN: Este artículo presenta los primeros resultados del estudio realizado sobre los cabildos catedralicios de Santiago y Orense durante el reinado de Felipe V. El objetivo fundamental se centra en dar a conocer la estructuración del personal de las catedrales, es decir, el número y ocupaciones de los capitulares, su procedencia geográfica para el caso compostelano, las relaciones de parentesco y la interrelación de sus miembros con los gobiernos locales de Santiago y Orense.

Palabras clave: cabildos; Galicia; Felipe V; personal; relaciones de parentesco; gobierno local.

* El presente estudio se ha realizado en el marco del proyecto de investigación Galicia y la instauración de la monarquía borbónica: poder y dinámica política (HAR2012-37007) financiado por el Ministerio de Economía y Competitividad.

(C) Ediciones Universidad de Salamanca / ®@ Stud. his., H. ${ }^{a}$ mod., 39, n. 1 (2017), pp. 403-449 
MARÍA SEIJAS MONTERO Y LAURA RODICIO PEREIRA

LOS CABILDOS CATEDRALICIOS DE SANTIAGO Y ORENSE EN EL REINADO DE FELIPE V: ALGUNOS RESULTADOS

ABSTRACT: This article describes the preliminary results from the study conducted on the Chapters of the Cathedrals of Santiago and Orense during the reign of King Felipe V. The main objective is to make known the structuring of the Cathedrals' staff, that is, the total number and occupation of the Chapter members, and in the case of Santiago Cathedral their geographical origin, the kinship among these and the interrelationship of these members with Santiago and Orense's local governments.

Key words: Cathedral Chapters; Galicia; Felipe V; Staff; Kinship; Local Government.

\section{INTRODUCCIÓN}

El mundo de los cabildos catedralicios, aun con enormes lagunas, no es con mucho de los menos estudiados desde hace décadas, en especial en el mundo hispánico, pero también en otros espacios geográficos como el francés, el inglés y, en menor medida, el italiano, el portugués o el germánico ${ }^{1}$. Nuestro objetivo con este artículo es ofrecer un primer avance de los cabildos de Santiago y Ourense, siendo plenamente conscientes de que se trata de la presentación de resultados de investigación muy provisionales. Nos interesa en estas páginas, sobre todo, contribuir al mejor conocimiento del personal que conformaba los dos cabildos gallegos, pues solo así, creemos honestamente, podremos avanzar en el estudio de ambas instituciones. Los dos casos presentados no son casuales. Estamos ante dos instituciones muy diferentes, lo que probablemente nos permitirá hacer una aproximación al tema capitular desde dos perspectivas distintas. Santiago, cabeza de archidiócesis y con un amplio dominio jurisdiccional era en época moderna uno de los cabildos más ricos de España, en buena medida porque contaba con una importante renta, el Voto de Santiago, que suponía la mitad de los ingresos de su mesa capitular en el siglo xvi y las tres cuartas partes a partir de entonces ${ }^{2}$. Al contrario, Ourense no destacaba, como cabildo medio que era, ni por su volumen de ingresos ni por su importancia jurisdiccional. Evidentemente, el volumen de

1. Un breve recorrido por la producción historiográfica que clarifique el estado actual de los conocimientos, además de revisar las posibilidades que ofrecen las fuentes y reflexionar sobre lo que aún queda por saber de los cabildos de Santiago y Orense lo hemos hecho en nuestro artículo «Los cabildos catedralicios de Santiago y Ourense en el reinado de Felipe V: estado de la cuestión, fuentes y perspectivas de investigación». Publicado en Tiempos Modernos, 8, 36, 2016, pp. 230-248.

2. Rey Castelao, O.: «El Voto de Santiago. Claves de un conflicto (I)», Compostellanum, 37, 1-2, 1992, p. 277.

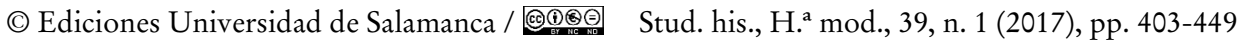


MARÍA SEIJAS MONTERO Y LAURA RODICIO PEREIRA

LOS CABILDOS CATEDRALICIOS DE SANTIAGO Y ORENSE EN EL REINADO DE FELIPE V: ALGUNOS RESULTADOS

documentación que ambas instituciones generaron no podía ser el mismo, pues tampoco lo eran sus necesidades. Si en Santiago la importancia y extensión de sus rentas y atribuciones provocó una importante burocratización, Orense permaneció durante la mayor parte del período moderno bajo administración directa. Este desigual punto de partida se ve agravado por el hecho de que una parte de la documentación orensana se encuentra sin catalogar. Así pues, dos realidades casi antagónicas, pero representativas de lo que puede ocurrir a la hora de iniciar una investigación sobre el clero capitular. Además, el hecho de haber elegido un cabildo sufragáneo y otro metropolitano nos permite volver a poner el acento en la necesidad, tantas veces anunciada, de diversificar y entrecruzar fuentes diferentes para obtener conclusiones a un nivel general y poder así compararlo con lo que ya sabemos en la actualidad.

El actual estado de nuestras investigaciones, y las lógicas limitaciones de espacio, nos han obligado a ceñir nuestra investigación a la primera mitad del siglo xviII. Por ello hemos dejado fuera un momento clave -un hito relevante- como fue la firma del concordato de 1753. En futuras investigaciones, en las que se pretende ampliar el marco cronológico a toda la centuria, intentaremos abordar esta cuestión para conocer cómo incidió la intervención política de la Corona en el sistema beneficial y los principales cambios que se produjeron en las corporaciones gallegas.

Ya se ha dicho que estas páginas se centran especialmente en dar conocer la composición y el número de miembros que formaron parte de ambos cabildos. Para lograr este objetivo se ha elaborado una base de datos con los miembros de las dos instituciones que tenemos documentados en el período analizado, lo que nos ha permitido hacer una reconstrucción de las series capitulares. Prestamos también atención a la procedencia geográfica de los capitulares compostelanos, pues la falta de fuentes no nos ha permitido hacer lo mismo para el caso orensano. Hemos hecho un primer esbozo de los lazos de parentesco dentro de las corporaciones capitulares y con los miembros de otras instituciones civiles y eclesiásticas. Hemos dejado fuera muchas cuestiones que atañen tanto a la estructura capitular como al análisis sociológico, pero la intención es abordarlas en futuros trabajos.

\section{El cabildo de Santiago en la primera mitad del XViII}

El cabildo de Santiago, aunque con una existencia previa, alcanza su plena conformación en el siglo XI cuando Diego Peláez (1071-1088) establece veinticuatro canónigos que, en teoría, debían vivir en comunidad con su obispo. Una cifra que asciende a setenta y dos en la siguiente centuria, número que refleja el de los discípulos de Jesucristo, durante el episcopado de Diego Gelmírez (1100-1140), momento en el que también se instauran los siete cardenales titulares de las parro-

(C) Ediciones Universidad de Salamanca / ®@ Stud. his., H. ${ }^{a}$ mod., 39, n. 1 (2017), pp. 403-449 
MARÍA SEIJAS MONTERO Y LAURA RODICIO PEREIRA

LOS CABILDOS CATEDRALICIOS DE SANTIAGO Y ORENSE EN EL REINADO DE FELIPE V: ALGUNOS RESULTADOS

quias de la ciudad, sin canonicato hasta el siglo xIV, pero formando parte del cabildo como dignidades. La autonomía económica de los canónigos quedó garantizada en el XII -poco antes de alcanzar la dignidad metropolitana-con la creación de la mesa capitular, separada de la del obispo, que les aseguraba unos bienes y rentas propios $^{3}$. Por su parte, el arzobispo Fonseca III (1507-1523) dicta las primeras constituciones capitulares en 1511. La aplicación de la normativa de Trento supuso mayores exigencias para acceder a las canonjías. Con las constituciones del arzobispo Gaspar de Zúñiga en 1569 se recortaron las libertades del cabildo, marcando nuevas pautas litúrgicas y administrativas, pero la definitiva implantación de las reformas vino de la mano del arzobispo Francisco Blanco. A él se deben las Constituciones capitulares aprobadas en 1578 y vigentes hasta finales del $\mathrm{XIX}^{4}$.

Ya desde el período medieval en la catedral compostelana se puede establecer una clara división interna entre dignidades, canónigos y racioneros. Entre las veinte dignidades enumeradas en las Constituciones de 1578, el deán era la cabeza visible y el máximo supervisor del clero capitular ${ }^{5}$. Sus funciones principales consistían en presidir las reuniones capitulares, proponer los asuntos que se iban a tratar, ejecutar lo acordado y vigilar que se respetasen los estatutos. Cuando no estaba presente, sus facultades recaían en un vicario designado por él, y en ausencia de ambos, en la dignidad más antigua ${ }^{6}$.

3. Pérez Rodríguez, F. J.: «Los cabildos catedralicios gallegos en la Edad Media (siglos XII-XIV)», Semata: Ciencias Sociais e Humanidades, 22, 2010, pp. 161-163.

4. Las constituciones de 1578 mencionan 58 prebendas en las que se incluyen las nuevas canonjías de oficio y otras plazas creadas en el siglo xvi. Desde entonces apenas se modificó el número de miembros del cabildo, ni tampoco su estructura interna. BARreiro MALlóN, B.: «La diócesis de Santiago en la época moderna", en García Oro, J. (coord.): Historia de las diócesis españolas. Iglesias de Santiago de Compostela y Tuy, 14. Madrid, 2002, p. 270. En este trabajo se han consultado las constituciones reimpresas en el siglo xvin y conservadas en la Biblioteca de la Universidad de Santiago: Constituciones establecidas por el Illustrisimo i Reverendisimo Señor son Francisco Blanco, Arzobispo de Santiago: juntamente con los Illustrisimos Señores Dean y Cabildo de la dicha Santa Iglesia, i con su consentimiento, para el buen govierno de ella, ansi en lo que toca al servicio del Altar, $i$ Coro, $i$ Oficios de los Prebendados, i otros Ministros, como al Cabildo, i conservación de la Hacienda de la Mesa Capitular. Santiago, 1781.

5. En las constituciones las dignidades aparecen por orden de antigüedad: deán, chantre, arcediano de Nendos, arcediano de Cornado, arcediano de Trastamara, arcediano de Salnés, cardenal mayor, seis cardenales, ordenados por antigüedad, maestrescuela, tesorero, arcediano de Reina, arcediano de Santiago, juez de Luou, prior de Sar y prior de Santiago. Constituciones establecidas por el Illustrisimo..., p. 2. El juez de Luou usa el nombre de arcediano en algunas escrituras notariales del siglo xvi, en la centuria siguiente se alterna el uso del nombre de juez y/o arcediano de Luou y a partir del xviII se llama únicamente arcediano. $C f r$. IgLEsias OrTEgA, A.: La Catedral de Santiago de Compostela y sus capitulares: funcionamiento y sociología de un cabildo en el siglo XVI. La Coruña, 2012, p. 74.

6. Constituciones establecidas por el Illustrisimo..., p. 3.

(C) Ediciones Universidad de Salamanca / ®@ Stud. his., H. ${ }^{a}$ mod., 39, n. 1 (2017), pp. 403-449 
MARÍA SEIJAS MONTERO Y LAURA RODICIO PEREIRA

LOS CABILDOS CATEDRALICIOS DE SANTIAGO Y ORENSE EN EL REINADO DE FELIPE V: ALGUNOS RESULTADOS

La segunda dignidad era la de chantre, encargado de presidir el coro y las procesiones dentro y fuera de la catedral y vigilar la buena marcha de los oficios religiosos. La constitución quinta se dedica al oficio de maestrescuela que debía «corregir los que erraren, i acentuaren mal las lecciones, i oficios que cantaren, e instruirá los ministros para que lo digan como conviene». También se encargaba de custodiar los dos sellos capitulares, agrupar la correspondencia recibida en dos legajos y escribir las cartas del cabildo; en este último caso estaría en posesión de dos libros: uno, en el que quedaba registro de las cartas de justicia o gobernación y otro para las de gracia. Entre las competencias del tesorero estarían la custodia del Tesoro de la catedral, el nombramiento del campanero y de tres sacristanes (uno para el altar de Santiago, otro para el del Sagrario y otro para el cuidado de los libros del coro), o la custodia del sello del altar de Santiago «con que a de sellar los testimonios que diere a los peregrinos, de cómo han visitado esta Santa Iglesia» ${ }^{7}$.

La constitución séptima se dedica a las nueve dignidades que no tienen renta en la mesa capitular (los seis arcedianos, el juez de Luou y los dos priores) indicando «que ganen la tercia parte de sus rentas en distribuciones cuotidianas, conforme al Santo Concilio de Trento». Así, al arcediano de Nendos le pertenecerían 100.000 maravedíes, los mismos que al prior de Sar, 56.250 al arcediano de Trastámara, 40.471 al de Salnés y Santiago, 30.000 al de Cornado, 12.500 al arcediano de Reina y prior de Santiago y, por último, al juez de Luou «ninguna cosa le señaló (el arzobispo Gaspar de Zúñiga) porque no tiene renta». En la constitución octava se hace un resumen del origen de los siete cardenales presbíteros compostelanos, cuya función principal era la de turnarse semanalmente para celebrar las misas en el altar mayor y asistir al prelado en las misas pontificales ${ }^{8}$. Las siete canonjías catedralicias tenían anexa a su dignidad una de las parroquias urbanas de Santiago. El cardenal mayor era el titular de Santa María de la Corticela, inclusa en la propia catedral, y los otros seis se repartían las parroquias de San Bieito do Campo, Santo André, Santa María Salomé, San Fiz de Solovio, Santa Susana y San Miguel dos Agros.

A continuación, estaban los canónigos sin dignidad que atendían el servicio en el coro y en el cabildo. Además algunos llevaban un oficio anexo a su prebenda, eran los canónigos de oficio y el maestro de capilla. Las canonjías de oficio eran cinco (doctoral, lectoral de sagrada escritura, lectoral de decretos, magistral y penitenciario) y tres se cubrían mediante oposición (doctoral, magistral y lectoral

7. Constituciones establecidas por el Illustrisimo..., pp. 4-7.

8. La transcripción del origen de los cardenales puede verse en Iglesias Ortega, A.: La Catedral de..., p. 89.

(C) Ediciones Universidad de Salamanca / ®@ Stud. his., H. ${ }^{a}$ mod., 39, n. 1 (2017), pp. 403-449 
de escritura), del mismo modo que la canonjía del magisterio de capilla. Las constituciones de Francisco Blanco establecen que la canonjía doctoral, creada en 1563 , sea provista por el prelado, el deán y el cabildo en un licenciado o doctor en cánones, admitiéndose como opositores a los doctores en leyes desde finales del xvi'. Su obligación principal era la de asesorar al cabildo y defenderle en los pleitos. El canónigo lector de escritura, independiente de la magistralía desde 1567, proveído como el doctoral y erigido de acuerdo con lo dispuesto en el concilio de Trento, era el encargado de dar lecciones en la catedral «a la hora y la materia que el prelado le señalare». El deán de la catedral compostelana se encargaba de presentar la lectoralía de decretos, instituida en 1506, para la cual debía elegir a un licenciado o doctor en cánones o leyes, graduado por universidad aprobada. Este canónigo debía defender los negocios de la Iglesia, siempre que hubiese necesidad y leer la cátedra de Decretos en la universidad compostelana. Entre las competencias del magistral, experto en teología y proveído por oposición, estaba la de predicar en la catedral los sermones programados, para lo que se le exigía el grado universitario de licenciado o maestro en teología. Por último, la canonjía de penitenciario, que se institucionaliza en los años sesenta del xvi, era proveída por el arzobispo en un licenciado o doctor en teología o cánones como así lo decretaba el concilio tridentino. Como especialista en moral estaba obligado a responder a las dudas y casos de conciencia que le consultasen, y confesar a los ministros de la iglesia cuando lo pedían.

En lo que respeta al maestro de capilla su provisión le correspondía al arzobispo, al deán y al cabildo. La primera canonjía del maestro de capilla fue proveída en junio de 1563, después de suprimir un canonicato a favor de la mesa capitular para el estipendio y porción del citado maestro ${ }^{10}$. Debía jurar los estatutos, como el resto de los canónigos, y sus obligaciones como maestro, pero no entraría en cabildo ni tendría voto en él para que estuviese desocupado y cumpliese su oficio como debía. Entre sus funciones principales, además de dirigir la capilla de música, estaría la de tener en su casa seis mozos de coro, que debía alimentar y vestir y hacerles «leer i escribir, i enseñarles a cantar canto llano, i de órgano, i contrapunto». Estas enseñanzas eran extensibles a los cantores, acólitos y demás prebendados que lo deseasen, dos horas al día, una por la mañana y otra por la tarde, excepto en las fiestas de guardar ${ }^{11}$.

9. Iglesias Ortega, A.: La Catedral de..., p. 102.

10. Idem, p. 105.

11. Constituciones establecidas por el Illustrisimo..., pp. 18-21.

(C) Ediciones Universidad de Salamanca / ®@ Stud. his., H. ${ }^{a}$ mod., 39, n. 1 (2017), pp. 403-449 
MARÍA SEIJAS MONTERO Y LAURA RODICIO PEREIRA

LOS CABILDOS CATEDRALICIOS DE SANTIAGO Y ORENSE EN EL REINADO DE FELIPE V: ALGUNOS RESULTADOS

La constitución décima se dedica a los racioneros, es decir, el grupo intermedio entre el clero mayor y menor, que, como ha señalado A. Iglesias, fue evolucionando desde una posición más cercana al segundo hacia una situación más próxima al primero, como grupo inferior del clero mayor. El mismo autor afirma que en teoría, desde comienzos del xvi, doce eran las raciones existentes en la catedral compostelana, aunque algunos años coinciden más de doce y a finales de siglo solo existían nueve racioneros titulares, pues tres prebendas fueron suprimidas para dotar al sochantre y a dos cantores ${ }^{12}$. Las constituciones de Francisco Blanco mencionan también a nueve racioneros que estaban «obligados a decir por su turno de semanas las Epístolas de todas las misas que se cantan en el Altar mayor i cuando el cabildo sale en Procesión fuera de la Iglesia» ${ }^{13}$.

Los resultados obtenidos para la primera mitad del xviII permiten reconstruir la sucesión de las 20 dignidades compostelanas, las cinco canonjías de oficio -incluida la del maestro de capilla-, las 28 canonjías titulares y las 9 raciones. Más difícil es conocer el valor de las prebendas pues los ingresos individuales dependían de la cantidad a repartir, del número de individuos, del rango de cada uno y de su grado de asistencia al coro y al culto ${ }^{14}$. Dicho esto, solo se pueden dar cifras aproximadas. El valor de la ración rondaba los 6.600 reales anuales y el de las canonjías en torno a los 20.000 reales. Más dispares eran los valores de las dignidades que se movían entre los 23.000 y los 39.000 reales $^{15}$.

Más fácil es conocer la procedencia geográfica de los capitulares con el objetivo de comprobar si eran naturales de la misma región en la que se situaba el cabildo compostelano $^{16}$ :

12. Iglesias Ortega, A.: La Catedral de..., pp. 109-111.

13. Constituciones establecidas por el Illustrisimo..., p. 11.

14. Rey Castelao, O.: «La financiación de la fábrica catedralicia compostelana, siglos XVII-XIX», Semata: Ciencias Sociais e Humanidades, 22, 2010, p. 318.

15. Bulas de titulos de canonjias, dignidades y raciones, ACS, IG 201 e IG 202. Una problemática, conocer el rendimiento exacto de las prebendas, que ya ha sido señalada por diferentes autores. LATORRE Ciria, J. M.: Economía y religión. Las rentas de la catedral de Huesca y su distribución social (siglos XVI-XVII). Zaragoza-Huesca, Instituto Fernando el Católico-Instituto de Estudios Altoaragoneses, 1992, pp. 285-302; Irigoyen López, A.: Entre el cielo y la tierra, entre la familia y la institución: el Cabildo de la Catedral de Murcia en el siglo XVII. Murcia, 2001, p. 142; DíAz RodríGueZ, A. J.: El clero catedralicio en la España moderna: los miembros del Cabildo de la Catedral de Córdoba (1475-1808). Murcia, 2012, p. 67.

16. El listado de dignidades, canónigos y racioneros titulares de la catedral compostelana en la primera mitad del XVIII aparece en las tablas del apéndice. Los resultados son provisionales y pueden tener alguna laguna ya que este trabajo no es una investigación cerrada, por lo que en un futuro se podrán seguir actualizando. Con estas líneas queremos hacer llegar nuestro sincero agradecimiento a Arturo Iglesias por los importantes datos biográficos -especialmente

(C) Ediciones Universidad de Salamanca / ®@ Stud. his., H. ${ }^{a}$ mod., 39, n. 1 (2017), pp. 403-449 
MARÍA SEIJAS MONTERO Y LAURA RODICIO PEREIRA

LOS CABILDOS CATEDRALICIOS DE SANTIAGO Y ORENSE EN EL REINADO DE FELIPE V: ALGUNOS RESULTADOS

TABla 1: Procedencia geográfica de los capitulares compostelanos ${ }^{17}$

\begin{tabular}{|c|c|c|c|c|c|c|c|c|c|c|c|}
\hline \multicolumn{3}{|c|}{ Dignidades } & \multicolumn{3}{|c|}{ Canónigos } & \multicolumn{3}{|c|}{ C. Oficio } & \multicolumn{3}{|c|}{ Racioneros } \\
\hline Origen & N. ${ }^{\circ}$ & $\%$ & Origen & N. ${ }^{\circ}$ & $\%$ & Origen & N. ${ }^{\circ}$ & $\%$ & Origen & N. ${ }^{\circ}$ & $\%$ \\
\hline Galicia & 34 & 48,6 & Galicia & 49 & 57,0 & Galicia & 13 & 50,0 & Galicia & 20 & 74,1 \\
\hline C. la Nueva & 12 & 17,1 & C. la Vieja & 16 & 18,6 & C. la Nueva & 4 & 15,4 & C. la Vieja & 4 & 14,8 \\
\hline Andalucía & 7 & 10 & C. la Nueva & 6 & 7,0 & C. la Vieja & 3 & 11,5 & C. la Nueva & 2 & 7,4 \\
\hline Asturias & 5 & 7,1 & P. Vascas & 3 & 3,5 & Asturias & 1 & 3,8 & Andalucía & 0 & 0,0 \\
\hline C. la Vieja & 3 & 4,3 & León & 2 & 2,3 & Andalucía & 0 & 0,0 & P. Vascas & 0 & 0,0 \\
\hline León & 2 & 2,9 & Navarra & 2 & 2,3 & P. Vascas & 1 & 3,8 & Se ignora & 1 & 3,7 \\
\hline P. Vascas & 2 & 2,9 & Andalucía & 1 & 1,2 & Se ignora & 4 & 15,4 & Total & 27 & 100 \\
\hline Extremadura & 1 & 1,4 & Asturias & 1 & 1,2 & Total & 26 & 100 & & & \\
\hline Valencia & 1 & 1,4 & Se ignora & 6 & 7,0 & & & & & & \\
\hline Se ignora & 3 & 4,3 & Total & 86 & 100 & & & & & & \\
\hline Total & 70 & 100,0 & & & & & & & & & \\
\hline
\end{tabular}

Fuente: Elaboración propia a través de los datos de Iglesias Ortega, A.: «Los expedientes de limpieza del Archivo Catedralicio de Santiago de Compostela: un elenco de los canónigos compostelanos», Compostellanum, 45, 1 y 2, 2000, pp. 301-337.

La tabla 1 demuestra que ha sido posible identificar el origen de 195 capitulares de los 209 que, por lo menos, formaron parte del cabildo en la primera mitad del xviII, lo que equivale al $93,3 \%$ del total, un porcentaje muy significativo y fiable para el conjunto de la institución capitular. Lo primero que llama la atención es la preponderancia de los gallegos, un 55,5\% del total, porcentaje superior en el caso de los canónigos sin oficio y los racioneros. De los 116 gallegos, 76 (64,7\%) procedía de la provincia de Santiago, seguida de La Coruña con 13 miembros $(11,2 \%)$ y Lugo $11(9,5 \%)$. Tuy ocupa el cuarto puesto con 7 (6\%), pero muy cerca de Orense que aportaba $6(5,2 \%)$ y Betanzos $4(3,4 \%)$. Al comparar estos porcentajes con los elaborados por A. Iglesias para las dos primeras centurias de la modernidad se comprueba que en la primera mitad del xvi el origen de los gallegos era del $40 \%$, proporción que desciende un punto y medio en los primeros cincuenta años del XVII, coincidiendo con la crisis económica de la centuria, y se

los obtenidos del vaciado de las informaciones de limpieza de sangre- que nos ha proporcionado tan amablemente sobre los capitulares compostelanos.

17. Las cifras totales de esta tabla y las que aparecen en el apéndice final no coinciden ya que algunos capitulares ocuparon varios cargos y la procedencia geográfica solo se contabiliza una vez.

(C) Ediciones Universidad de Salamanca / ®@ Stud. his., H. ${ }^{a}$ mod., 39, n. 1 (2017), pp. 403-449 
MARÍA SEIJAS MONTERO Y LAURA RODICIO PEREIRA

LOS CABILDOS CATEDRALICIOS DE SANTIAGO Y ORENSE EN EL REINADO DE FELIPE V: ALGUNOS RESULTADOS

recupera en la segunda mitad (54,05\%). El resultado que obtiene entre 1700-1752 $(58,08 \%)$ es un poco más elevado, pero hay que tener en cuenta que el marco cronológico es diferente (1680-1750 en el presente caso) y además incluye a los racioneros músicos y sochantres -una buena parte gallegos- que no han sido analizados en este estudio por pertenecer al clero menor. De lo que no hay duda es del proceso de «galleguización» que se produce a partir del siglo XviI ${ }^{18}$.

Tras los pretendientes gallegos, el segundo lugar lo ocuparían los procedentes de ambas Castillas -con un porcentaje que supera el 11\%-y oriundos de las antiguas provincias de Madrid, Toledo, La Mancha, Guadalajara, Cuenca, Burgos, Valladolid y Soria. Los naturales de Andalucía (Córdoba, Granada, Jaén y Sevilla) aportaban el 3,8\%, en consonancia con la extensión del Voto de Santiago al sur peninsular, y los de Asturias y Vascongadas en torno al $3 \%{ }^{19}$. Finalmente, los leoneses representaban el 1,9\% y los navarros, extremeños y valencianos no superaban en ningún caso el $1 \%$ del total.

Es evidente, por lo tanto, la capacidad de atracción que ejercía en la Corona de Castilla (99,5\%) -al fin y al cabo muchos clérigos estudiaban en las universidades castellanas y el cabildo compostelano era un potente foco de atracción-, pues un único capitular era originario de la Corona de Aragón ${ }^{20}$. Esta presencia castellana también ha sido confirmada en los obispos del reino de Galicia, el clero regular gallego y el propio cabildo compostelano ${ }^{21}$. Una endogamia geográfica muy presente en otros

18. Iglesias Castelao, A.: «Análisis sociológico del cabildo compostelano a través de los expedientes de limpieza de sangre», Compostellanum, 41:3-4, 2000, pp. 430-431. IgLesias ORTEGA, A.: «Sociología capitular: el ejemplo del cabildo de la catedral de Santiago de Compostela en el siglo XVI», Obradoiro de historia moderna, 20, 2011, p. 394.

19. A. Iglesias ya ha señalado que en el período 1700-52 aparecen representadas dieciséis diócesis más (especialmente andaluzas) que en el de 1545-99. Esta ampliación puede estar relacionada con la que se verifica en la estructura de los ingresos del cabildo por la expansión del Voto de Santiago, pues como afirma O. Rey la mayor importancia del Voto Nuevo de Granada, que comprendía Castilla la Nueva, Badajoz, Andalucía y Murcia, en estos ingresos explicaría el mayor número de prebendados nacidos en las diócesis andaluzas que lo costeaban. IGLESIAS Ortega, A.: «Sociología capitular...», p. 433. Sobre el Voto de Santiago véase Rey Castelao, O.: «La renta del Voto de Santiago y las instituciones jacobeas», Compostellanum, 3-4, 1985, pp. 336-354.

20. Se trata de Carlos Juan Francisco de Borja Ponce de León y Centellas, prior de Sar, natural de la ciudad de Gandía (diócesis de Valencia) en donde nació el 28/02/1663. Informaciones de Limpieza, Archivo Catedral de Santiago [en adelante ACS], leg. 734, n. ${ }^{\circ}$ 9, 1708.

21. Barrio Gozalo, M.: «Perfil socioeconómico de una élite de poder, III: Los obispos del reino de Galicia (1600-1840)», Anthologica Annua, 32, 1985, pp. 34-35. Rey Castelao, O.: «Cistercienses y benedictinos en la Galicia moderna: evolución numérica y análisis social», Actas del Congreso Internacional sobre San Bernardo e o Císter en Galicia e Portugal, 2. Orense, 1992, vol. 2, pp. 316-323. Rey Castelao, O. y Barreiro Mallón, B.: «El clero regular mendicante

(C) Ediciones Universidad de Salamanca / ®@ Stud. his., H. ${ }^{a}$ mod., 39, n. 1 (2017), pp. 403-449 
MARÍA SEIJAS MONTERO Y LAURA RODICIO PEREIRA

LOS CABILDOS CATEDRALICIOS DE SANTIAGO Y ORENSE EN EL REINADO DE FELIPE V: ALGUNOS RESULTADOS

capítulos peninsulares como el gaditano, giennense o cordobés, entre otros ${ }^{22}$. De todas formas, si bien el origen geográfico no era un obstáculo para formar parte del cabildo metropolitano, los buenos contactos familiares con miembros del capítulo facilitaban a los futuros candidatos la entrada en la institución capitular.

Son numerosos los ejemplos de las relaciones de parentesco entre los capitulares de la primera mitad del xviII ya que algunos de los apellidos que conforman la nómina catedralicia se repiten con bastante frecuencia. De esta manera los prebendados ayudarían a muchos de sus parientes a ascender en la carrera eclesiástica. De los treinta y dos apellidos repetidos localizados entre los capitulares compostelanos, veinticuatro -cerca del $30 \%$ del colectivo- pertenecían a un mismo grupo familiar ${ }^{23}$. Y sin duda, la relación de parentesco más habitual era la de tío-sobrino, algo lógico, pues como ha señalado Antonio Irigoyen para el cabildo murciano, cuando se quería asegurar el mantenimiento de la prebenda dentro de la familia se recurría a uno de sus miembros jóvenes, habitualmente, con la entrega del beneficio a un sobrino por medio de la vía extraordinaria de coadjutoría ${ }^{24}$. Dicho de otro modo, cuando la transmisión se daba por coadjutoría, la Santa Sede garantizaba el derecho a futura sucesión irrevocable en el beneficio a la muerte del titular ${ }^{25}$.

en Galicia: evolución numérica, procedencia social y comportamientos de los franciscanos (ss. XVI-XIX)», Archivo Ibero-americano, 49:195-196, 1989, p. 477. Iglesias CastelaO, A.: "Análisis sociológico del...», p. 431.

22. Morgado García, A. J.: «El alto clero gaditano durante el Antiguo Régimen (16001833)», Studia Historica. Historia Moderna, 16, 1997, pp. 231-132. Coronas Vida, L. J.: «Los miembros del cabildo catedral de Jaén (1700-1737)», Chronica Nova, 15, 1986-1987, pp. 108-110. Vázquez Lesmes, R.: Córdoba y su Cabildo catedralicio en la modernidad. Córdoba, 1987, p. 91. Díaz Rodríguez, A. J.: El clero catedralicio..., pp. 128-133.

23. Como hermanos se han localizado al lectoral Benito y al canónigo Domingo Estévez de Castro; al racionero Francisco y al canónigo José Ramón Hernández de Uzal; a los cardenales Ignacio, Antonio y Francisco Mella Varela; a los canónigos Manuel y José Benito y a los arcedianos de Reina Pedro y Gregorio Posse de Soto; a los canónigos Julián y Domingo Santa María y San Martín; o a los canónigos Juan y Bernardo Valladares y Somoza.

24. Irigoyen López, A.: Entre el cielo..., p. 268. Las relaciones de parentesco dentro de las instituciones capitulares también han sido tratadas, entre otros, por DíAz RodRíGuez, A. J.: «Cabildos catedralicios y clero capitular en el Antiguo Régimen: Estado de la cuestión», Revista de historiografía, 13, 2010, p. 86; El nepotismo capitular del siglo XVI en la catedral compostelana lo ha estudiado Iglesias Ortega, A.: La Catedral de..., pp. 449-494.

25. Ejemplos de estas concesiones entre parientes consanguíneos fueron las de los racioneros Alonso de Orgeira y su sobrino Domingo García Orgeira, que le sucedió en 1727; los cardenales Luís y José Bermúdez de Castro; los racioneros Francisco y Manuel García Abadiano, que recibió la ración en 1722; Pedro Mahía y Lago, que dejaría la ración a su sobrino Miguel Pereira y Mahía y este al suyo Miguel José Pereira; los cardenales Gabriel de la Huerta y Juan de la Cuesta y Huerta; los arcedianos de Trastámara Baltasar y Álvaro Eugenio Mendoza; los canónigos Antonio e Ignacio Fariña, que le sucede en 1710 y a este su también sobrino José

(C) Ediciones Universidad de Salamanca / ®@ Stud. his., H. ${ }^{a}$ mod., 39, n. 1 (2017), pp. 403-449 
MARÍA SEIJAS MONTERO Y LAURA RODICIO PEREIRA

LOS CABILDOS CATEDRALICIOS DE SANTIAGO Y ORENSE EN EL REINADO DE FELIPE V: ALGUNOS RESULTADOS

En ocasiones el beneficio mediante coadjutoría también se transmitía a otros parientes. Fue el caso del racionero Francisco Bantiñán y Orgeira que sucedió a su primo Domingo García Orgeira en 1740; Juan José Armesto y Astorga hizo lo propio con su primo Juan Llanos y Astorga; el cardenal Francisco Mella Varela, sucesor de su hermano Antonio; Francisco de Salazar, que lo fue de su primo Manuel Pérez de Villanueva y Salazar; o el arcediano de Reina Gregorio Posse de Soto, que había recibido la transmisión de su hermano Pedro. Como vía extraordinaria de ingreso en el cabildo se utilizaban también las resignas, obtenidas en Roma, cuando el poseedor renunciaba a la prebenda y nombraba sucesor. Un ejemplo claro fue el de Bernardo Valladares que utilizó la resigna para cederle la canonjía a su hermano Juan Valladares en $1749^{26}$. Así, este sistema de provisión se convirtió, hasta la firma del concordato de 1753, en una forma de burlar el mecanismo ordinario de proveer las prebendas -le correspondían al papa las que vacasen en los ochos meses apostólicos y al arzobispo y cabildo las que lo hiciesen en los meses ordinarios de marzo, junio, septiembre y diciembre-, de tal manera que estas eran concedidas por sus propietarios en coadjutoría o resigna con pensión a personas, muchas veces parientes, que no siempre eran las más idóneas para ocupar la prebenda ${ }^{27}$.

El resultado de este sistema de provisión trajo como consecuencia la formación de un sólido entramado de linajes capitulares, similar al de otras catedrales peninsulares, en que una misma familia se perpetuaba en el cabildo a través de algunos de sus miembros, incluso por varias generaciones, hasta el punto de que se puede hablar de la patrimonialización de algunas prebendas. La duración en la institución de cada linaje variaba desde los dos individuos -once casos en los que se registra la transmisión de la prebenda- a los tres -en cuatro ocasiones-, es decir, lo más habitual sería no superar las dos generaciones de los tíos-sobrinos ${ }^{28}$. Cuando no se produce la transmisión de la prebenda se constatan diez casos en los que varios parientes coinciden algunos años en distintas canonjías, confirmándose

Antonio Fariña; Andrés Ruiz Ruiz y Andrés Ruiz Gallo «el mozo» que accede a la canonjía en 1720; Felipe y Julián de Santa María, que lo hace en 1721; o Pablo Valladares, al que sucedería su sobrino Bernardo Valladares en 1740.

26. Informaciones de limpieza de sangre, ACS, IG 730-IG 775; Libros de posesiones y muertes (ss. XVII-XVIII), ACS, Pte. Sign., s.f. y Posesiones y Vacantes (XVIII-XIX), ACS, Pte. Sign.

27. El sistema de resignas y coadjutorías para acceder a las prebendas catedralicias fue muy frecuente en los cabildos castellanos, véase BARRio GozAlo, M.: El clero en la España moderna. Córdoba, 2010, pp. 222-229.

28. Dos miembros se han localizado en los linajes Bermúdez de Castro, García Abadiano, Huerta, Mella, Mendoza Caamaño, Omaña, Posse de Soto, Ruiz, Salazar, Santa María y Astorga. Se sucedieron tres miembros en los linajes de Orgeira, Fariña, Mahía y Pereira y Valladares.

(C) Ediciones Universidad de Salamanca / ®@ Stud. his., H. ${ }^{a}$ mod., 39, n. 1 (2017), pp. 403-449 
MARÍA SEIJAS MONTERO Y LAURA RODICIO PEREIRA

LOS CABILDOS CATEDRALICIOS DE SANTIAGO Y ORENSE EN EL REINADO DE FELIPE V: ALGUNOS RESULTADOS

así que es más factible conseguir una prebenda catedralicia en la iglesia de Santiago si ya se tiene una pariente dentro de la comunidad capitular ${ }^{29}$.

Los expedientes de limpieza de sangre también permiten conocer el número de prebendados cuyos progenitores o familiares detentaron regidurías, no solo en el municipio compostelano, sino también en otras ciudades y villas gallegas. Así, se han localizado veintiséis individuos (12,4\% del total) con ascendientes o parientes colaterales regidores, principalmente, en la ciudad de Santiago (50,0\%), pero también en las de Lugo (11,5\%), Betanzos (7,7\%), La Coruña, Mondoñedo, Orense o Tuy (3,8\% en cada caso) y en las villas de Vigo (7,7\%), Pontevedra y La Guarda (3,8\%).

Al analizar los datos de Santiago, que son los que aquí nos interesan (tabla 2), se observa que seis capitulares fueron hijos de regidores en la primera mitad del XVIII ${ }^{30}$. De todos ellos, solo el alcalde y regidor Sebastián Granado Catalán

29. Domingo Cayetano Estévez de Castro fue canónigo diez años antes de que su hermano Benito Estévez dejara la canonjía lectoral; Manuel Granado Catalán ocupó la canonjía doctoral entre 1685-1714 y su sobrino Esteban Granado fue racionero desde 1710 hasta 1753 . Antonio Guiráldez fue tesorero entre 1725-1741 y su hermano Luís Bernardo canónigo entre 1739-1783. José Ramón Hernández de Uzal disfrutó de una canonjía desde 1747 y su hermano Francisco de una ración tres años después. Los hermanos Ignacio y Antonio Mella coincidieron como cardenales desde 1731 y su tío Antonio Manuel con su sobrino Antonio desde 1704. También coincidieron algunos años José Benito Manuel Posse, Manuel Antonio, canónigos, y su hermano Pedro Antonio, Arcediano de Reina. Pedro Antonio Riaño ocupó el cargo de cardenal mayor entre 1713-1729 y su hermano Juan Antonio el de canónigo desde 1712 hasta 1726. Finalmente Manuel Silvestre de Yanguas fue canónigo entre 1701-1749 y su hermano Juan Yanguas canónigo desde 1710. Informaciones de limpieza de sangre, ACS, IG 738, IG 744, IG 749, IG 771, IG 772 e IG 773; Libros de posesiones y muertes (ss. XVII-XVIII), ACS, Pte. Sign. s/f.

30. En todo el siglo xvi la cifra que obtiene Arturo Iglesias es de veinte capitulares hijos de regidores. Vid. Iglesias Ortega, A.: «Élites eclesiásticas y sociedad en el siglo xvi: la extracción social de los capitulares compostelanos», Estudios humanisticos. Historia, 10, 2011, p. 23. En Canarias el estudio de los testamentos de los capitulares proporciona un porcentaje del 26,9\% de hijos de regidores para el xvi, en el xvir el 35\% tiene a padre o hermano/s ejerciendo el cargo de regidor y en la siguiente centuria los miembros del cabildo con parientes en los ayuntamientos insulares disminuye hasta el 15,4\%. Vid. Quintana Andrés, P. C.: «El cabildo catedral de Canarias. Una élite socioeconómica e ideológica de ámbito regional», Revista de historia moderna: Anales de la Universidad de Alicante, 26, 2008, p. 223. En Cádiz en el siglo XVIII ocho prebendados eran hijos de regidores, corregidores o alcaldes mayores. Morgado García, A. J.: «El alto clero gaditano durante el Antiguo Régimen (1600-1833)», Studia Historica. Historia Moderna, 16, 1997, p. 231. En otros cabildos como el murciano las familias de la oligarquía local no mostraron gran interés en que sus miembros ocupasen puestos en el cabildo catedralicio. Vid. Irigoyen López, A.: Entre el cielo..., p. 172. Tampoco debe pasar inadvertido que al acudir a la lista de regidores de Santiago en la segunda mitad del xviII, publicada por Eduardo Cebreiros, se puede comprobar que el 15\% comparten apellidos con algunos canónigos y dignidades del cabildo eclesiástico aunque por el momento se desconoce

(C) Ediciones Universidad de Salamanca / ®@ Stud. his., H. ${ }^{a}$ mod., 39, n. 1 (2017), pp. 403-449 
MARÍA SEIJAS MONTERO Y LAURA RODICIO PEREIRA

LOS CABILDOS CATEDRALICIOS DE SANTIAGO Y ORENSE EN EL REINADO DE FELIPE V: ALGUNOS RESULTADOS

Tabla 2: Parientes regidores de los capitulares en el concejo de Santiago (1700-1750)

\begin{tabular}{|c|c|c|c|}
\hline CAPITULAR & CARGO & REGIDOR & $\begin{array}{c}\text { PARENTESCO CON } \\
\text { EL CAPITULAR }\end{array}$ \\
\hline Becerra de Moscoso, Fructuoso & Canónigo & Juan Becerra de Nebra & Bisabuelo paterno \\
\hline $\begin{array}{c}\text { Caamaño y Taboada, Juan } \\
\text { Francisco }\end{array}$ & Canónigo & Andrés de Mondragón & Tío abuelo materno \\
\hline $\begin{array}{l}\text { Cisneros y Sarmiento, Fran- } \\
\text { cisco Jerónimo }\end{array}$ & $\begin{array}{l}\text { Arcediano de } \\
\text { Nendos }\end{array}$ & $\begin{array}{c}\text { Bernardino Cisneros Figue- } \\
\text { roa y Mendoza }\end{array}$ & Padre \\
\hline Estévez de Castro, Benito & $\begin{array}{l}\text { Lectoral de } \\
\text { decretos }\end{array}$ & Andrés Ferreiro de la Torre & Abuelo materno \\
\hline $\begin{array}{c}\text { Ferreiro de la Torre, Lucas } \\
\text { Antonio }\end{array}$ & Canónigo & Andrés Ferreiro de la Torre & Hermano \\
\hline Granado Catalán, Esteban & $\begin{array}{l}\text { Racionero y } \\
\text { canónigo }\end{array}$ & Sebastián Granado Catalán & Padre \\
\hline $\begin{array}{c}\text { Guiráldez y Ordoñez, Antonio } \\
\text { Benito Jacobo }\end{array}$ & Tesorero & $\begin{array}{c}\text { Nicolás Guiráldez Romero } \\
\text { de Caamaño }\end{array}$ & Padre \\
\hline Mallón Blanco, Ambrosio & Canónigo & Gregorio García Mallón & Padre \\
\hline Pazo y Torre, Ignacio Bernardo de & $\begin{array}{l}\text { Cardenal } \\
\text { mayor }\end{array}$ & Andrés Ferreiro de la Torre & Tío materno \\
\hline $\begin{array}{c}\text { Porras y Gayoso, Andrés } \\
\text { Gerónimo de }\end{array}$ & Racionero & Juan de Porras y Figueroa & Padre \\
\hline $\begin{array}{c}\text { Sánchez de Vaamonde y } \\
\text { Andrade, Juan }\end{array}$ & $\begin{array}{l}\text { Arcediano de } \\
\text { Nendos }\end{array}$ & $\begin{array}{l}\text { Gregorio Sánchez de } \\
\text { Vaamonde }\end{array}$ & Padre \\
\hline $\begin{array}{c}\text { Vaamonde Varela y Valenzuela, } \\
\text { Agustín de }\end{array}$ & Canónigo & Pedro Sánchez Vaamonde & Abuelo paterno \\
\hline $\begin{array}{l}\text { Vega y Calo Vallo de Porras, } \\
\text { Felipe Jacobo Nicolás de la }\end{array}$ & Cardenal & Martín Rodríguez de la Vega & Abuelo paterno \\
\hline
\end{tabular}

Fuente: Elaboración propia a través de los datos extraídos de las Informaciones de limpieza de sangre (ACS).

era de origen foráneo, pues había nacido en la villa de la Mota. Dos habían nacido en Santiago: Bernardino Cisneros, natural de la parroquia de San Fiz de Solovio, regidor perpetuo, alcalde ordinario y ministro del Santo Oficio y Nicolás Guiráldez, de la misma vecindad, que ocupó los cargos de regidor perpetuo y alguacil mayor del servicio de millones en Santiago y su provincia,

el tipo de parentesco que tenían. Vid. Cebreiros Álvarez, E.: El municipio de Santiago de Compostela a finales del Antiguo Régimen (1759-1812). Santiago, 1999, pp. 126-130.

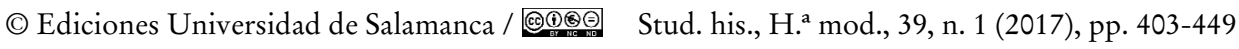


MARÍA SEIJAS MONTERO Y LAURA RODICIO PEREIRA

LOS CABILDOS CATEDRALICIOS DE SANTIAGO Y ORENSE EN EL REINADO DE FELIPE V: ALGUNOS RESULTADOS

y fue además dueño del coto de Oines, casas de Magulán, Dodro y Leboráns ${ }^{31}$. Por su parte, Gregorio Sánchez de Vaamonde, era natural de Santiago de Bascoi, jurisdicción de Mesía y señor de las casas de Lens, Castro y Gondelle; Juan de Porras y Figueroa, regidor más antiguo de la ciudad, había nacido en la feligresía de Piloño ${ }^{32}$; y Gregorio García Mallón, regidor y ministro del Santo Oficio, era natural de la jurisdicción de Xallas.

En línea recta descendente tres prebendados eran nietos de los regidores Pedro Sánchez Vaamonde, alcalde comisario del Santo Oficio y natural de San Vicenzo de Curtis; de Martín Rodríguez de la Vega, tesorero de la Santa Cruzada, descendiente de los Vegas que llegaron a la ciudad compostelana con la erección del Hospital Real, fundado por los Reyes Católicos en las postrimerías del siglo xv; y del regidor perpetuo y alcalde ordinario Andrés Ferreiro de la Torre, natural de Santiago y fundador en 1708 del vínculo del Pazo de Vistalegre ${ }^{33}$. Las vinculaciones familiares se completan con las del cardenal mayor Ignacio Pazo y Torre, cuyo tío materno era el referido Andrés Ferreiro de la Torre y el canónigo Fructuoso Becerra de Moscoso, bisnieto del capitán Juan Becerra de Nebra, vecino de Santiago; finalmente, en un grado de afinidad más lejano estaría Juan Francisco Caamaño y Taboada, sobrino nieto de Andrés de Mondragón, marqués de Santa Cruz, caballero de la orden de Santiago y regidor perpetuo de la citada ciudad.

En definitiva, de estos datos se deduce la vinculación del cabildo catedralicio con la élite municipal durante el período moderno, a fin de cuentas la pertenencia a estas instituciones era muy apreciada, ya que en ellas se adquiría poder y honor, y además permitía a ciertos clanes familiares ejercer un gran control sobre la ciudad. Sin embargo, esta afirmación tiene que ser, necesariamente, provisional. Es necesario hacer estudios más amplios y cruzar las listas de los miembros de ambas corporaciones, solo así podremos conocer las verdaderas conexiones familiares que se dieron entre el poder civil y religioso.

31. El padre de Bernardino, Antonio de Cisneros fue regidor perpetuo de Santiago y alcalde ordinario en 1672. Informaciones de Limpieza, ACS, leg. 736, n. 9, 1726. También el padre de Nicolás, Luís Guiráldez de Caamaño, fue regidor perpetuo y alguacil mayor de millones de Santiago y familiar del Santo Oficio. Informaciones de Limpieza, ACS, leg. 772, n. ${ }^{\circ}$ 6, 1724.

32. El oficio de regidor de Santiago también había sido ocupado anteriormente por el abuelo paterno del prebendado, Gonzalo de Porras, y el materno, Juan de Gayoso, que fue además familiar del Santo Oficio, regidor y alférez mayor de Orense. Informaciones de Limpieza, ACS, leg. 757, n. ${ }^{\circ} 5,1711$.

33. El regidor Andrés Ferreiro de la Torre era además hermano del canónigo Lucas Antonio Ferreiro de la Torre. Informaciones de Limpieza, ACS, leg. 740, n. ${ }^{\circ} 1,1712$.

(C) Ediciones Universidad de Salamanca / ®@ Stud. his., H. ${ }^{a}$ mod., 39, n. 1 (2017), pp. 403-449 
MARÍA SEIJAS MONTERO Y LAURA RODICIO PEREIRA

LOS CABILDOS CATEDRALICIOS DE SANTIAGO Y ORENSE EN EL REINADO DE FELIPE V: ALGUNOS RESULTADOS

\section{El CABILdo de ORENSE EN LA PRIMERA MitAd DEL XVIII}

La estructura interna del cabildo de Orense sufrió notables cambios a lo largo del tiempo. Algo a lo que contribuyó, sin duda, la ausencia de un marco legislativo que regulase la vida capitular en todos sus aspectos. Este vacío se cubrió en 1634 con la promulgación de las Constituciones de don Diego de Zúniga y Sotomayor, vigentes hasta mediados del XIX, aunque una parte de su contenido ya había quedado anulado mediante diferentes acuerdos capitulares ${ }^{34}$.

En Orense había un total de «treinta y dos prebendas en que se distribuye y divide la renta de la Mesa Capitular». Pero esto no implicaba que hubiese el mismo número de canonicatos. De hecho, a principios del xviII uno estaba reservado para la inquisición y otro anexo a la dignidad de tesorero. A estos habría que sumarle las seis prebendas reservadas a los doce racioneros. El resultado es que el número máximo de canónigos era de dieciocho, pero ni todos eran iguales ni necesariamente se llegó a completar dicho cupo. A grandes rasgos, se puede clasificar a los canónigos orensanos en tres grupos en función de las condiciones de acceso que les exigían. El primero estaba formado por los ocho canónigos presbiteriales o cardenales que tenían que demostrar haber recibido la ordenación sacerdotal. Tras ellos se situaban los cuatro canónigos de oficio u oposición que debían acreditar haber recibido formación universitaria. Finalmente, entre los canónigos simples o de gracia podían repartirse hasta doce prebendas. Sin embargo, fue frecuente que alguna de estas canonjías se anexara a las dignidades para completar así su dotación ${ }^{35}$.

Dentro del cabildo existían importantes diferencias jerárquicas. En la cúspide se situaban las doce dignidades: deán, chantre, arcedianos de Castela, Limia, Baronceli y Búbal, tesorero, maestrescuela, abad de Celanova, abad de la Trinidad, arcediano de Orense y vicario. Esta última, estaba unida a la mesa episcopal. Por su parte, los abades de la Trinidad y Celanova tampoco eran capitulares en sentido estricto, pues ambos títulos iban anexos al superior de la institución correspondiente ${ }^{36}$.

34. Hemos utilizado una copia manuscrita de las constituciones que se conserva en la sección clero del Archivo Histórico Provincial de Orense [en adelante AHPO, Clero, 496]. A partir de ahora citadas como: Constituciones de don Diego de Zúñiga.

35. Los problemas económicos que atravesó la fábrica en la segunda mitad del XviII provocaron que se acordase reservarle dos canonicatos, el primero en 1765 y el segundo al año siguiente. Archivo Catedralicio de Orense [en adelante ACO], Actas Capitulares, Pte. Sign. Barreiro Mallón, B.: «La diócesis de Ourense en la Edad Moderna», en García Oro, J. (coord.): Historia de las diócesis españolas. Iglesias de Lugo, Mondoñedo-Ferrol y Orense, 15. Madrid, 2002, pp. 499-500. El listado de dignidades y canónigos de la catedral orensana puede verse en las tablas del apéndice.

36. No está claro cuál era el orden de preferencia e importancia de estas dignidades. Las Constituciones establecen el que aquí se ha utilizado. Sin embargo, en la España Sagrada el

(C) Ediciones Universidad de Salamanca / ®@ Stud. his., H. ${ }^{a}$ mod., 39, n. 1 (2017), pp. 403-449 
MARÍA SEIJAS MONTERO Y LAURA RODICIO PEREIRA

LOS CABILDOS CATEDRALICIOS DE SANTIAGO Y ORENSE EN EL REINADO DE FELIPE V: ALGUNOS RESULTADOS

El deán era el presidente del cabildo y, por lo tanto, la más alta dignidad. Sus funciones y obligaciones variaban en función de la catedral. En general, era el encargado de vigilar el funcionamiento de los negocios capitulares y de que el culto se desarrollase en circunstancias adecuadas. Para llevar a cabo esta función contaba con una serie de potestades especiales, reconocidas por las constituciones, que le conferían autoridad para sancionar al resto de capitulares. Prueba de su importancia era que daba nombre a uno de los lados del coro, el del evangelio. Sus ausencias prolongadas obstaculizaban tanto la dinámica capitular, que se estableció en las constituciones la posibilidad de nombrar un vicario que le sustituyera. Cuando su salud se lo permitía era el propio deán quien lo elegía, pero en caso de incapacidad la potestad le correspondía al cabildo ${ }^{37}$.

El chantre era la siguiente dignidad en importancia. Presidía el coro de la epístola, se encargaba de la música en los oficios, de la disposición y organización de los asistentes a la liturgia y de que el maestro de ceremonias pusiese «los rótulos de Semana Santa y de los Pontificales». Además, tenía obligación de dotar al sochantre y asegurarse de que hiciera «la tabla del servicio del altar y coro todos los sábados» ${ }^{38}$.

arcediano de Limia queda en una posición posterior al abad de la Trinidad y el vicario aparece como tercero en importancia. El motivo de este cambio se nos escapa. De hecho, en el XviII el arcediano de Limia era una de las dignidades que más participa de la dinámica capitular. Para época medieval Pérez Rodríguez agrupa a las dignidades por importancia siguiendo el patrón clásico y relega a los arcedianos a una posición posterior al tesorero y al maestreescuela. BARREIRO Mallón, B.: «La diócesis de...», pp. 499-500. Duro Peña, E.: «Las antiguas Dignidades de la Catedral de Orense», Anuario de Estudios Medievales, 1, 1964, pp. 289-332. Pérez RodríGUEz, F. J.: «La diócesis de Orense: de la reforma gregoriana al Concilio de Trento», García Oro, J. (coord.): Historia de las diócesis españolas. Madrid, 2002, vol. 15, pp. 441-451. Flórez, E.: España Sagrada. 1763, vol. 17, pp. 210-211. Rodicio Pereira, L.: O cabido catedralicio de Ourense (1788-1808): Aproximación á Institución e aos seus componentes. Trabajo Fin de Máster, Universidad de Vigo, 2012.

37. La existencia de un vicario o subdeán fue frecuente en otras catedrales como la de Ávila o la de Huesca. En opinión de Pérez Rodríguez en Orense esta dignidad desapareció y quedó unida a la mesa. Pérez Rodríguez, F. J.: «La diócesis de...», pp. 441-451. Villacorta Rodríguez, T.: El Cabildo Catedral de León. León, 1974, pp. 83-136. Existen interesantes trabajos sobre esta figura. CANDel Crespo, F.: Deanes de la Catedral de Murcia (siglos XIII al XX). Murcia, 2005. Cal Pardo, E.: «Los Deanes de la Catedral de Mondoñedo», Estudios Mindonienses, 26, 2010, pp. 61-146. DíAz Rodríguez, A. J.: «Las casas del deán don Juan de Córdoba. Lujo y clientela en torno a un capitular del Renacimiento», Hispania Sacra, 61, 123, 2009, pp. 77-104. Hernández Figueiredo, J. R.: «Actas del deán Bedoya durante la sede vacante de Orense (1841-1847)», Anthologica Annua, 55-56, 2008-2009, pp. 411-632. SANZ DE la Higuera, F. J.: «El deán burgalés Calderón de la Barca (1704-1773). Un modelo de clérigo en el Setecientos», Historia y Genealogía, 4, 2014, pp. 7-30.

38. PÉrez Rodríguez, F. J.: «La diócesis de...», pp. 441-451. Una perfecta caracterización de esta figura a nivel institucional en Villacorta Rodríguez, T.: El Cabildo Catedral..., pp. 83-136. Algunos estudios sobre el papel concreto de otros chantres y sus funciones pueden verse

(C) Ediciones Universidad de Salamanca / ®@ Stud. his., H. ${ }^{a}$ mod., 39, n. 1 (2017), pp. 403-449 
MARÍA SEIJAS MONTERO Y LAURA RODICIO PEREIRA

LOS CABILDOS CATEDRALICIOS DE SANTIAGO Y ORENSE EN EL REINADO DE FELIPE V: ALGUNOS RESULTADOS

La tercera de las dignidades era el maestrescuela, encargado de dirigir la escuela de la catedral, de corregir los libros que se usaban en los oficios y de supervisar los documentos producidos por el cabildo. La primera mención sobre esta dignidad data de 1217, cuando el arzobispo de Braga manda nombrar un maestro para enseñar a los niños. Probablemente, al igual que ocurrió en Santiago, esta sería la última de las dignidades principales en aparecer ${ }^{39}$.

La custodia de las propiedades, el tesoro y el archivo catedralicio eran competencia del tesorero. A nivel económico, sus rentas se situaban sobre diferentes derechos que se cobraban en la catedral y de los que percibía una parte. Además, para garantizarle un mínimo de sustento, se le unió una prebenda ${ }^{40}$.

Por lo que respecta al abad de la Trinidad, su aparición se remonta al siglo xiv. Siguiendo las constituciones era la última de las dignidades por orden jerárquico. Su inclusión dentro del catálogo de capitulares se debió, probablemente, a su riqueza hacendística, que tuvo su origen en los tiempos en los que se concede la carta de dotación a la catedral. En este documento se estipulaba que una parte del coto quedaría bajo su control para hacer frente a las necesidades derivadas de su actividad asistencial. No era habitual que asistiera y tampoco llevaba canonicato anexo ${ }^{41}$.

Finalmente, de las doce dignidades aurienses cinco eran arcedianos: Limia, Baronceli, Castela, Bubal y Celanova. Sin embargo, su nombre no iba necesariamente

en Barrios Manzano, M. P.: «Las funciones de chantre, sochantre y maestro de canto llano en la catedral de Coria (Cáceres) 1590-1750», Cuadernos de arte de la Universidad de Granada, 26, 1995, pp. 73-82. DíAz IвÁ́̃̃EZ, J.: «Carrera eclesiástica e inquietudes religiosas de un clérigo castellano del siglo xv. Nuño Álvarez de Fuente Encalada, chantre de la Iglesia de Cuenca», En la España medieval, 36, 2013, pp. 263-326. GonzÁlez García, M. Á.: «Don Alonso de Piña, Chantre de Ourense, Prior de Xunqueira de Ambía, mecenas y hombre de gobierno", Escritos dedicados a José María Fernández Catón. León, 2004, vol. 1, pp. 571-596. Iglesias Almeida, E.: «D. Lope García Sarmiento, un orensano Chantre de Tui», Porta da Aira, 3, 1990, pp. 219-226.

39. Constituciones de don Diego de Zúniga, fol. 5r. Pérez Rodríguez, F. J.: «La diócesis de...», pp. 441-451. Villacorta Rodríguez, T.: El Cabildo Catedral..., pp. 83-136.

40. Le correspondía una parte de los diezmos cobrados en la ciudad, un tercio de lo recogido como ofrenda en la catedral y la capilla de Santa María la Madre, y la mitad de lo que se ingresase por determinados conceptos como los entierros o el hacer sonar las campanas. Constituciones de don Diego de Zúniga: 5r. Libro de las posesiones y derechos de la Fábrica y del Cabildo de Orense en 1777, ACO, Pte. Sign.: 3v. Pérez Rodríguez, F. J.: «La diócesis de...», pp. 441-451; Villacorta Rodríguez, T.: El Cabildo Catedral..., pp. 83-136.

41. En otros cabildos también fue habitual la representación de las abadías seglares de la ciudad. Así ocurre en León con los abades de San Marcelo y San Esteban, en Burgos con los de Foncea, Cervatos, Salas, San Quirce, Castrojeriz, San Millán y Garmonal o en Toledo con el abad de San Vicente y Santa Leocadia, por citar solo algunos ejemplos. Gonzalo Gozalo, Á.: El cabildo de la catedral de Burgos en el siglo XIX (1808-1902). Burgos, 1993, pp. 25-29; LoP Oтín, M. J.: El cabildo catedralicio de Toledo en el siglo XV. Aspectos institucionales y sociológicos. Madrid, 2003, pp. 168-170; Pérez RodrígueZ, F. J.: «La diócesis de...», pp. 441-451; ViLlacorTA Rodríguez, T.: El Cabildo Catedral..., pp. 83-136. Constituciones de don Diego de Zúñiga: 6r.

(C) Ediciones Universidad de Salamanca / ®@ Stud. his., H. ${ }^{a}$ mod., 39, n. 1 (2017), pp. 403-449 
MARÍA SEIJAS MONTERO Y LAURA RODICIO PEREIRA

LOS CABILDOS CATEDRALICIOS DE SANTIAGO Y ORENSE EN EL REINADO DE FELIPE V: ALGUNOS RESULTADOS

vinculado a su capacidad de actuar como tales. Es de sobra conocido que un arcedianato era el territorio en el que el titular ejercía las funciones episcopales, lo que no impedía que el obispo pudiera ejercerlas directamente en caso de considerarlo necesario. Lo particular del caso orensano era que esta función no sería exclusiva de las dignidades que reciben el nombre de arcedianos ni común a todas ellas. Así, los de Limia, Baronceli, Castela y Bubal disfrutaban de ese derecho, pero no el arcediano de Orense. Por el contrario, el deán, chantre y maestreescuela, a pesar de no tener el título, sí gozaban de ese derecho. Al margen quedaría el arcediano de Celanova cuyas prerrogativas iban más allá ya que, como abad del monasterio del mismo nombre, le correspondían también el señorío territorial y jurisdiccional. En cualquier caso, todos estos arcedianatos respondían a una realidad y organización territorial anterior. El abad de la Trinidad, el arcediano de Orense y el tesorero no recibieron esa condición seguramente porque se crearon con posterioridad y en ese momento ya no había un espacio disponible ${ }^{42}$.

La naturaleza del arcediano de Orense, era diferente. De hecho, en la documentación manejada, en muchas ocasiones, aparece como arcediano titular, una nomenclatura ya de por sí elocuente. Su dotación económica procedía de los diezmos, frutos y rentas de Santiago de Toubes y entre sus obligaciones estaría poner capellanes, la paletilla y es apuntador en las pontificales y ordenes generales. Quizás el rasgo más característico de este arcediano era la obligación de residencia, que en caso de incumplimiento le podía suponer la pérdida de todos los frutos de la Dignidad ${ }^{43}$.

Siguiendo las constituciones, en Orense había ocho canónigos presbiteriales, conocidos tradicionalmente como cardenales, aunque no hay constancia de una bula papal de concesión del título. Esta figura probablemente se creó a imitación del cabildo compostelano, en tiempos del obispo Diego Velasco, responsable de la reorganización capitular orensana y miembro de aquella institución. En origen, este tipo de canonjías estarían mejor dotadas que el resto y su número debió ser inferior, pues en estos momentos no era fácil encontrar individuos que hubiesen recibido el orden presbiterial ${ }^{44}$.

La situación a principios del XviII no parece que distara mucho de lo legislado en las constituciones. Los ochos cardenales orensanos gozaban en este momento, y

42. Barreiro Mallón, B.: «La diócesis de...», pp. 499-500; Duro PeÑa, E.: «Las antiguas Dignidades..., pp. 289-332; Flórez, E.: España Sagrada. 1763, vol. 17, pp. 210-211. PÉrez Rodríguez, F. J.: «La diócesis de...», pp. 441-451; Villacorta Rodríguez, T.: El Cabildo Catedral..., pp. 83-136.

43. Constituciones de don Diego de Zúniga, fol. 5v.

44. Pérez Rodríguez, F. J.: «La diócesis de...», pp. 441-451.

(C) Ediciones Universidad de Salamanca / ®@ Stud. his., H. ${ }^{a}$ mod., 39, n. 1 (2017), pp. 403-449 
MARÍA SEIJAS MONTERO Y LAURA RODICIO PEREIRA

LOS CABILDOS CATEDRALICIOS DE SANTIAGO Y ORENSE EN EL REINADO DE FELIPE V: ALGUNOS RESULTADOS

ya desde su creación, de una serie de obligaciones y privilegios que los distinguían del resto. Eran los únicos que tenían derecho a misar en el altar mayor sin necesidad de colocar un altar portátil. Además debían «por su turno tomar capas en las vísperas, y misa en las cinco fiestas que hay maitines cantados e incensar cuando hay incienso y hay cuatro capas». Cada semana, uno de ellos hacía de semanero correspondiéndole la obligación de «comenzar a capitular y decir las oraciones en las horas canónicas». Mientras este no llegaba sus obligaciones recaían en aquel a quien le hubiese tocado esa labor en el turno anterior ${ }^{45}$.

Había además cuatro canonicatos de oficio: lectoral, doctoral, magistral y penitenciario. Las condiciones que debían cumplir fueron reguladas a partir del concilio de Trento y se difundieron por los cabildos hispánicos, entre ellos, el de Orense. Todos compartían una exigencia común: debían ser graduados universitarios. Su provisión se hacía por oposición, para lo cual solía seguirse un ritual similar. Dentro de un plazo de tiempo que no podía exceder los dos meses, salvo por causa justificada, debían emitirse los edictos firmados por el prelado -o provisor en su ausencia-, por el deán y ratificarse por el secretario capitular. Estos edictos eran colocados en la puerta de la catedral y de las principales universidades de la época. El canónigo magistral debía ser licenciado o doctor en teología por alguna de las universidades del Reino de Castilla y de León o bien del colegio de Bolonia. Las constituciones no especifican con claridad cuál era su cometido, pero probablemente, al igual que en el resto de ejemplos conocidos, se encargarían de predicar en el púlpito. Por su parte, el penitenciario debía ser un licenciado o doctor en cánones o teología. Su función fundamental era «responder a las dudas y casos de conciencia por palabra o por escrito cuando fuere preguntado y en las confesiones de todos los penitentes que con él se quieren confesar, absolverá de los casos reservados». El doctoral tenía que ser licenciado en cánones y estaba «obligado a decir su parecer de palabra o por escrito en todos los negocios tocantes a la Catedral y a la Dignidad Episcopal y más Dignidades con tal de que el pleito no sea entre el Prelado y el Cabildo, porque en tal caso ayudará al Cabildo». Por último, el lectoral, al que también se le exigía ser licenciado en cánones, era el encargado de dar la lección y los sermones siempre que el cabildo o el prelado se lo pidieran. Esta obligación la compartía con el penitenciario, pero a horas diferentes ${ }^{46}$.

45. Constituciones de don Diego de Zúñiga, fols. 7v-8r. Rodicio Pereira, L.: «Ser canónigo en Ourense a finales del siglo XviII», Diversarum Rerum, 8, 2013, pp. 135-158. VILlacorTA Rodríguez, T.: El Cabildo Catedral..., pp. 83-136.

46. Villacorta Rodríguez, T.: El Cabildo Catedral..., pp. 83-136. Sobre las canonjías de oficio ver Aranda Doncel, J.: «Los prebendados del cabildo catedralicio de Córdoba

(C) Ediciones Universidad de Salamanca / ®@ Stud. his., H. ${ }^{a}$ mod., 39, n. 1 (2017), pp. 403-449 
MARÍA SEIJAS MONTERO Y LAURA RODICIO PEREIRA

LOS CABILDOS CATEDRALICIOS DE SANTIAGO Y ORENSE EN EL REINADO DE FELIPE V: ALGUNOS RESULTADOS

De las restantes prebendas, dos estaban cedidas a la fábrica, una a la inquisición y la otra unida al tesorero. Además era habitual, aunque no estaba regulado por constitución, que las dignidades tuvieran un canonicato anexo. Correspondían, por lo tanto, un máximo de doce prebendas a repartir entre los canónigos simples cuya función principal era la de asistir a los oficios del coro y al culto en la catedral. También colaboraban en la gestión de los negocios del cabildo. La importancia de los canonicatos en las catedrales era tal que su prebenda, la canonjía, se utilizaba como unidad de reparto de las rentas de la mesa capitular. Los canónigos, aun siendo dignidades, tenían la obligación de «cantar por sus turnos y semanas los evangelios de las misas conventuales y las demás por estipendio de dos reales y llevar capa pluvial en el coro siempre que les tocara».

Por último, estarían los racioneros, también conocidos como porcioneros, que se situaban a medio camino entre el clero menor y el mayor. Cada ración estaba dotada con media prebenda; es decir, con la mitad de lo que cobraba un canónigo. Entre sus obligaciones se incluían la de leer la epístola de las misas conventuales que le tocasen en reparto semanal y, en las demás que lo hiciesen, ganarían «estipendio de real y medio ${ }^{47}$. Eran doce, de las cuales cuatro estaban reservadas a músicos elegidos mediante oposición. Además, era frecuente que de este grupo saliesen buena parte de los futuros canónigos, por lo que muchas veces la posesión de una ración era una de las vías de entrada elegidas por los que buscaban la promoción o ascenso hacia puestos más altos en la jerarquía eclesiástica. Los racioneros músicos tuvieron un comportamiento diferenciado, pues la

durante los siglos XVI y xvir: la provisión de la canonjía magistral», Cortés PeÑA, A. L. y LóPEZ GuAdAlupe Muñoz, M. L. (coords.): Estudios sobre Iglesia y sociedad en Andalucía en la Edad Moderna. Granada, 1999, pp. 137-152 y «Los canonicatos de oficio del cabildo catedralicio de Córdoba durante los siglos xvi y xvir: la provisión de la canonjía lectoral», Castellano, J. L. y López-Guadalupe Muñoz, M. L. (coords.): Homenaje a Antonio Dominguez Ortiz. Granada, 2008, pp. 55-80 y Olivares Terol, M. J.: «Las canonjías de oficio y oposición en el XVI murciano", Murgetana, 91, 1995, pp. 33-50. La relación existente entre el acceso a una prebenda y el lugar de formación ha sido estudiada en Carabias Torres, A. M.: «Catálogo de colegiales del Colegio Mayor de San Bartolomé (1700-1840)», Studia Historica. Historia Moderna, 9, 1991, pp. 43-88; «Salamanca, académica palanca hacia el poder», en Aranda PÉrez, F. J. (coord.): Letrados, juristas y burócratas en la España moderna. Cuenca, 2005, pp. 23-60 $\mathrm{y}$ «Evolución histórica del colegio mayor. Del siglo XIV al XXI», REDEX. Revista de educación de Extremadura, 5, 2013, pp. 67-81. Para el caso de Galicia vid. González García-Paz, S.: O Colexio de San Clemente de Pasantes de Compostela. Santiago de Compostela, 1993.

47. Constituciones de don Diego de Zúñiga, fols. 8r-8v y fol. 23r. Barreiro Mallón, B.: "La diócesis de...», pp. 471-508. Cánovas Botía, A.: Auge y decadencia de una institución eclesial: El cabildo catedral de Murcia en el siglo XVIII. Iglesia y sociedad. Murcia, 1994; PÉrEZ Rodríguez, F. J.: «La diócesis de...», pp. 441-451.

(C) Ediciones Universidad de Salamanca / ®@ Stud. his., H. ${ }^{a}$ mod., 39, n. 1 (2017), pp. 403-449 
MARÍA SEIJAS MONTERO Y LAURA RODICIO PEREIRA

LOS CABILDOS CATEDRALICIOS DE SANTIAGO Y ORENSE EN EL REINADO DE FELIPE V: ALGUNOS RESULTADOS

obtención de una ración fue un fin en sí mismo ${ }^{48}$. Frente a esto, muchos de los racioneros simples abandonaron su prebenda por promoción hacia otro puesto. En la primera mitad del Xviı resulta difícil cuantificar la incidencia de este fenómeno, pues las actas no siempre reflejan las posesiones de las raciones. No obstante, se han localizado dos ejemplos: Domingo Blanco de Araujo, provisto racionero en 1724 y elevado a la condición de canónigo presbiterial en 1742 y Manuel García del Valle, que obtuvo la media prebenda en 1725 y la canonjía simple en 1774 . Las actas señalan que fue una recompensa por los años de buen servicio, aunque en el primer caso la provisión le correspondió al cabildo y el segundo se situaba bajo patronato real. Una situación constatada también para la segunda mitad de la centuria. Así, entre 1788 y 1808 casi dos tercios de las vacantes, el 66,6\%, serían por este motivo. De hecho, algo más de la cuarta parte de las canonjías provistas, el $27,2 \%$, fueron destinadas a personas que habían tenido esa condición. Ninguno promocionaría a una prebenda de menor o igual valor, sino hacia puestos más elevados en la jerarquía eclesiástica. El 50\% accedería a una canonjía presbiterial, otro porcentaje significativo, en torno al 33,3\%, promocionaría a canonjías simples, y el resto se distribuiría a partes iguales entre canonjías de oficio y dignidades. No fue casual que la mayoría se orientaran hacia canonjías presbiteriales, al fin y al cabo eran las que más honor y prestigio social tenían dentro del cabildo orensano. Prueba de la importancia de este mecanismo en las estrategias familiares es el hecho de que la mayoría, 66,6\%, contaba en ese momento con algún familiar en el cabildo ${ }^{49}$.

En fin, esta era a grandes rasgos la estructura del cabildo orensano en un momento en el que dicha institución sufrió las consecuencias de las reformas filipinas, entre ellas, el aumento de la presión fiscal sobre la iglesia. No obstante, durante la primera mitad de la centuria persistieron las estrategias de patrimonialización de los cargos - coadjutoría, permuta o resigna- y continuaron siendo el obispo y el cabildo los encargados de la provisión de beneficios. Todo ello condiciona para que se pueda hablar de una época de «cambios y continuidades» ${ }^{50}$.

48. Un comportamiento semejante al registrado en Córdoba para los racioneros en general por Díaz Rodríguez, A. J.: El clero catedralicio..., 2012, p. 145. En Santiago en el siglo xvi poco más del $14 \%$ de los racioneros logran la promoción a puestos del cabildo. IgLESIAS ORTEGA, A.: La Catedral de..., 2012, p. 602.

49. Rodicio Pereira, L.: «Ser canónigo en...», pp. 135-158.

50. Sobre esta época ver Barrio Gozalo, M.: «El clero secular en el reinado de Felipe V (1701-1746)», en Pereiras Iglesias, J. L. (coord.): Felipe V de Borbón 1701-1746: actas del Congreso de San Fernando (Cádiz) de 27 de noviembre a 1 de diciembre de 2000. Córdoba, 2002, pp. 343-378 y «El clero en la España de Felipe V. Cambios y continuidades», en SERrano Martín, E. (coord.): Felipe V y su tiempo: congreso internacional. Zaragoza, 2004, vol. 1, pp. 287-322. Cortés PeÑa, A.: «La iglesia y el cambio dinástico», en Serrano Martín, E. (coord.): Felipe V y su tiempo: congreso internacional. Zaragoza, 2004, vol. 1, pp. 991-1012.

(C) Ediciones Universidad de Salamanca / ®@ Stud. his., H. ${ }^{a}$ mod., 39, n. 1 (2017), pp. 403-449 
MARÍA SEIJAS MONTERO Y LAURA RODICIO PEREIRA

LOS CABILDOS CATEDRALICIOS DE SANTIAGO Y ORENSE EN EL REINADO DE FELIPE V: ALGUNOS RESULTADOS

La ciudad de Orense era a principios de la centuria un territorio dominado por cuatro instituciones: el corregidor y el ayuntamiento, representantes de las instancias civiles, el obispo y el cabildo en el ámbito eclesiástico. Este sería el marco en el que interactuaban las élites a las que nos hemos querido aproximar a lo largo de este trabajo. Si el cabildo mantenía una estructura semejante a la de principios del xviI, el ayuntamiento se había visto afectado, desde su paso al realengo, por la venalidad municipal convirtiéndose en lo que López Díaz ha denominado «regimiento hipertrófico» y fuertemente oligarquizado ${ }^{51}$.

La elaboración de un índice prosopográfico de los capitulares orensanos de la primera mitad de siglo nos ha proporcionado datos interesantes. Sin ánimo de obtener conclusiones definitivas, pueden vislumbrarse algunos comportamientos característicos de este momento. Por un lado, se constata, del mismo modo que en otros cabildos, la presencia de una serie de familias que controlaron un gran número de prebendas y consiguieron transmitirlas dentro de su entorno más próximo ${ }^{52}$.

Un buen ejemplo lo constituye el linaje de los Guntín surgido en esta época. El primero en acceder al cabildo fue Benito Ventura Guntín Pillado, provisto como deán en 1715. En 1736, José Benito Álvarez Guntín se convierte en su coadjutor y a la muerte del anterior, en 1743, pasó a ocupar esta dignidad. Aunque se desconoce

González López, E.: El alba flor de lis. Galicia en los reinados de Felipe V, Luis I y Fernando VI. Sada, 1978; Irigoyen LóPEZ, A.: «Iglesia y sociedad en los primeros años del siglo XVIII según el obispo Belluga. Las relaciones "ad limina” de la diócesis de Cartagena (1705-1717)», en Serrano Martín, E. (coord.): Felipe V y su tiempo: congreso internacional. Zaragoza, 2004, vol. 1, pp. 415-428; Morgado García, A. J.: «Discursos eclesiásticos en la España de Felipe V. Los manuales de confesores», en Pereiras Iglesias, J. L. (coord.): Felipe V de Borbón 1701-1746: actas del Congreso de San Fernando (Cádiz) de 27 de noviembre a 1 de diciembre de 2000. Córdoba, 2002, pp. 435-466; Rey Castelao, O.: «Mutaciones sociales en una sociedad inmutable. El Reino de Galicia en el reinado de Felipe V», en SERrano Martín, E. (coord.): Felipe Vy su tiempo: congreso internacional. Zaragoza, 2004, vol. 1, pp. 343-374. La estructura del cabildo catedralicio a finales del XviII puede verse en Rodicio PEREIRA, L.: O cabido catedralicio..., 2012.

51. López Díaz, M.: «Élites locales y dinámicas de poder en la Galicia filipina: cambio dinástico y primeras tentativas reorganizadoras», en LóPEz DíAz, M. (ed.): Élites y poder en las monarquias ibéricas. Del siglo XVII al primer liberalismo. Madrid, 2013, pp. 99-128.

52. Para el caso gallego ver Barreiro Mallón, B.: «El clero de la diócesis de Santiago: estructuras y comportamientos (siglos XVI-XIX)», Compostellanum, 33, 1988, pp. 469-507; Bobillo VÁzQuez-Monjardín, M. Á.: «O Clero secular nunha cidade galega do século XVII, o caso de Ourense», Historia nova IV: contribución dos Xoves Historiadores de Galicia. Santiago de Compostela, 1996, pp. 31-44 y «Los Capitulares de la Catedral de Ourense ante la muerte en el siglo XviII», Boletín de Estudios del Seminario «Fontán-Sarmiento» de hagiografía, toponimia y onomástica de Galicia, 18, 1997, pp. 41-50; Iglesias Ortega, A.: La Catedral de..., 2012. Sobre otros cabildos ver Irigoyen López, A.: Entre el cielo..., 2001 y Díaz Rodríguez, A. J.: El clero catedralicio..., 2012.

(C) Ediciones Universidad de Salamanca / ®@ Stud. his., H. ${ }^{a}$ mod., 39, n. 1 (2017), pp. 403-449 
MARÍA SEIJAS MONTERO Y LAURA RODICIO PEREIRA

LOS CABILDOS CATEDRALICIOS DE SANTIAGO Y ORENSE EN EL REINADO DE FELIPE V: ALGUNOS RESULTADOS

el grado de parentesco, pues en la documentación no se especifica, la relación entre ellos parece evidente. De hecho, cuando muere Benito Ventura Guntín su sucesor en la dignidad sería también uno de sus albaceas. Con José Benito se inicia un verdadero linaje catedralicio que durante todo el siglo xviı coparía importantes cotas de poder. Muy pronto, en 1757, su hermano, Francisco Javier, llegaría a cardenal, puesto en el que permanecería hasta 1797 tras haber cumplido con más de cuarenta años de servicio. Precisamente, esta familia alcanzaría las máximas cotas de poder entre 1757, luego del nombramiento de Francisco Javier, y 1769, cuando fallece José Benito. Este linaje estaría muy ligado al archivo y biblioteca capitular y sus miembros aparecen citados en diferentes fuentes impresas de la época, como el Repertorio de don Juan de Nóvoa, que menciona a José Benito, o la España Sagrada, que agradece a Francisco Javier su ayuda. La desaparición de la coadjutoría y la entrada en vigor del Concordato de 1753 impediría que el deanato se pudiera transmitir a la siguiente generación, sin embargo, a principios del xIX un nuevo miembro lograría el acceso al cabildo, primero como racionero en 1804, y después como cardenal en $1806^{53}$.

Frente a la presencia de estas nuevas familias, viejas conocidas, como los Verea, están ausentes entre 1733, cuando muere Sebastián, y 1756 en que accedería Pedro Benito, ningún miembro de la familia formaría parte del cabildo. Circunstancia novedosa desde que en 1609 Mateo Verea consiguió la provisión de una canonjía. Otros linajes importantes, como los Temes o los Armada, desaparecerían por completo de las filas capitulares durante la primera mitad de siglo, aunque su presencia se constataría nuevamente en la segunda mitad de la centuria ${ }^{54}$.

Esta renovación capitular no implicaría la desaparición de la transmisión de la prebenda a través de la conexión de parentesco más habitual, la de tío-sobrino. Como en otros cabildos, el sistema elegido sería el de coadjutoría, pero no era el único. Este último aspecto resulta significativo, pues explicaría que cuando esta herramienta desaparezca se pueda seguir hablando de un cabildo fuertemente oligarquizado. Ya en esta época se percibe que el recurso a estas formas de transmisión era más frecuente y característico de linajes tradicionales como los Verea.

53. Estos datos y los citados a continuación proceden de un índice prosopográfico de elaboración propia a partir de datos extraídos de las actas capitulares (1700-1808), conservadas en el ACO, y de los protocolos notariales de la ciudad de Orense (1675-1820) conservados en el AHPO y en el Archivo Histórico Diocesano de Orense [en adelante AHDO]. GonzÁlez GarcíA, M. A.: «El archivo y la biblioteca», La catedral de Ourense. La Coruña, 1997, pp. 470-479. Flórez, E.: España 1763, vol. 17.

54. Hervella Vázquez, J.: «La capilla de la Asunción o de Argiz en la Catedral de Ourense. La ascendencia orensana del primer marqués de San Saturnino», Porta da Aira, 3, 1990, pp. 93-128.

(C) Ediciones Universidad de Salamanca / ®@ Stud. his., H. ${ }^{a}$ mod., 39, n. 1 (2017), pp. 403-449 
MARÍA SEIJAS MONTERO Y LAURA RODICIO PEREIRA

LOS CABILDOS CATEDRALICIOS DE SANTIAGO Y ORENSE EN EL REINADO DE FELIPE V: ALGUNOS RESULTADOS

Al contrario, otras familias recurrirían a la meritocracia o a colocar a sus vástagos en beneficios menores desde los que darían el salto a otras prebendas. Un ejemplo claro de este tipo de estrategias fue el de los Figueroa. El primero en acceder sería Francisco Figueroa, que en 1704 se convierte en coadjutor de Rodrigo Verjano. En 1733 su sobrino, Manuel Figueroa, ganaría la oposición a doctoral ${ }^{55}$.

La vinculación con otras instituciones, como el ayuntamiento, puede ser demostrada a través de la familia de los Guntín. Ya se ha dicho que Benito Ventura Guntín Pillado consiguió el deanato en 1715. Su hermano, Antonio José, ocuparía diferentes cargos militares en la provincia orensana hasta que en 1732 compraría un regimiento. El acceso al concejo probablemente supondría para este linaje el éxito de sus estrategias de promoción social, orientadas en varias direcciones: la eclesiástica, la militar o la civil. Resulta especialmente interesante el hecho de que sea el eclesiástico, Benito, el primero en conseguir un puesto de importancia, por lo que tal vez, sería el iniciador del ascenso familiar. Otras familias en las que se constata su vinculación con el ayuntamiento fueron los Espinosa o los Ulloa. Incluso se han localizado algunos linajes, como los Quiñones, relacionados con la ciudad de León o los Gallardo Pereira con la de Lugo ${ }^{56}$.

También existen importantes lazos con el clero parroquial de la provincia al que iban destinados algunos miembros de las familias. La presencia en el mundo rural también se fortalece mediante fundaciones pías y capellanías, práctica común dentro de las estrategias de promoción social de la época ${ }^{57}$. En este sentido es necesario llamar la atención sobre el hecho de que los capitulares orensanos aparecen como beneficiarios, pero también como fundadores. Un interesante ejemplo puede verse con los Verea, muy unidos con la parroquia de Santa María de Melias. Pero además, las élites que integraban el cabildo no desaprovecharon las oportunidades que ofrecía el clero regular e incluso, a medida que avanzaba el siglo, buscaron la connivencia con oficios emergentes que consiguieron importantes cotas de poder: mayordomos, médicos, etc. Tal fue el caso de Antonio Maneiro Sanmamed, arcediano en 1757, y cuyo hermano, Miguel, era el médico titular del concejo y el cabildo. Su otro hermano, Ambrosio, había ingresado en el monasterio

55. Un buen ejemplo fue el traspaso de Sebastián de su prebenda a su sobrino homónimo y coadjutor en 1702 .

56. López DíAz, M.: «Élites locales...», pp. 99-128.

57. Pro Ruiz, J.: «Las capellanías: familia, Iglesia y propiedad en el Antiguo Régimen», Hispania sacra, 41, 84, 1989, pp. 585-602; Seijas Montero, M.: «Las fundaciones pías de la catedral de Santiago: el ejemplo de Mencía de Andrade», Semata: Ciencias Sociais e Humanidades, 22, 2010, pp. 213-234; Soria MesA, E.: «Las capellanías en la Castilla Moderna: Familia y ascenso social», en Irigoyen López, A. y Pérez Ortiz, A. L. (coords.): Familia, transmisión y perpetuación (Siglos XVI-XIX). Murcia, 2002, pp. 135-150.

(C) Ediciones Universidad de Salamanca / ®@ Stud. his., H. ${ }^{a}$ mod., 39, n. 1 (2017), pp. 403-449 
MARÍA SEIJAS MONTERO Y LAURA RODICIO PEREIRA

LOS CABILDOS CATEDRALICIOS DE SANTIAGO Y ORENSE EN EL REINADO DE FELIPE V: ALGUNOS RESULTADOS

cisterciense de Oseira y los otros dos, Bartolomé y Domingo, pertenecían a la orden franciscana.

Por último, a lo largo del reinado de Felipe $\mathrm{V}$ tuvo lugar la formación de dos nuevos linajes que permiten hablar de un fenómeno diferente, ya constatado en el cabildo compostelano del xvi: el nepotismo episcopal, es decir, la tendencia de los obispos para favorecer a familiares y allegados que acabarían ocupando puestos de poder en la curia y el cabildo. Los linajes de los Ros de Medrano y los Cornejo así lo demuestran. En ambos casos se registraron varios individuos con este apellido tras el paso por el episcopado de un miembro de sus familias: Diego Ros de Medrano (1673-1694) y Damián Cornejo (1694-1704) ${ }^{58}$.

Los hermanos Miguel y José Cornejo, lograrían el acceso al cabildo en circunstancias aparentemente beneficiosas. El primero, se convertiría en canónigo en 1699 y solo un año después lograría la promoción a la dignidad de chantre. La carrera de José sería muy similar, en 1706 alcanzaría la condición de canónigo y arcediano de Baronceli y en 1714 ganaría la oposición a lectoral. Sin embargo, el poder de este linaje se mantendría solo en el primer cuarto del siglo, pues en cronologías posteriores no vuelven a aparecer entre las filas capitulares.

Al contrario los Ros de Medrano, cuyo origen habría que relacionarlo, probablemente, con el obispo homónimo, estarían presentes en la institución capitular durante todo el siglo xviII. En 1700 Antonio Castell Ros de Medrano fue designado canónigo y poco después maestreescuela, dignidad que hereda Joaquín Ros, su coadjutor desde 1706. Este último consigue ese mismo año la provisión a su favor de una de las cardenalías y a la muerte de su tío, en 1729, heredó la maestrescolía que ocuparía hasta su muerte en 1748. Años más tarde, en 1798, otro miembro de la saga lograría la provisión a su favor de una ración.

En fin, estas son solo algunas de las pautas de comportamiento que existieron en el clero capitular orensano en la primera mitad del xvirI. Esperamos que investigaciones futuras puedan corregir o corroborar la veracidad de lo hasta aquí señalado.

\section{Conclusiones}

A lo largo de estas páginas hemos intentando hacer una aproximación a dos élites de poder durante el reino de Felipe V. Es cierto que en los últimos años los avances en la investigación capitular han sido notables, sobre todo, en instituciones más importantes. Así, en el ámbito gallego sabemos muchísimo sobre el

58. Iglesias Ortega, A.: La Catedral de..., pp. 449-459.

(C) Ediciones Universidad de Salamanca / ®@ Stud. his., H. ${ }^{a}$ mod., 39, n. 1 (2017), pp. 403-449 
MARÍA SEIJAS MONTERO Y LAURA RODICIO PEREIRA

LOS CABILDOS CATEDRALICIOS DE SANTIAGO Y ORENSE EN EL REINADO DE FELIPE V: ALGUNOS RESULTADOS

cabildo compostelano en el siglo xvi gracias a la tesis doctoral de Arturo Iglesias y tenemos importantes estudios elaborados por los historiadores gallegos que ofrecen interesantes resultados sobre el alto clero. Lo fundamental está dicho, pero todavía son necesarios trabajos parciales que indaguen algunas sombras, maticen resultados y aborden las diferencias con otros cabildos. No cabe duda de que el cabildo de Santiago es una gran institución situada en una ciudad eminentemente clerical, sobre la que ejerció una enorme influencia. Esto nos sitúa ante la necesidad de seguir reconstruyendo su historia sin olvidar el marco social en el que se integra. En este artículo hemos intentado contribuir al mejor conocimiento del personal que conforma el cabildo compostelano reconstruyendo la sucesión de dignidades, canónigos y racioneros, analizamos su procedencia geográfica, $\mathrm{y}$ hemos hecho un primer esbozo sobre las relaciones familiares dentro de la corporación capitular y las vinculaciones de parentesco con las élites locales, solo nos queda seguir profundizando en estas y otras cuestiones con el objetivo de ampliar las investigaciones que ya se han realizado sobre diferentes aspectos del clero capitular compostelano y de otros ámbitos peninsulares. Somos conscientes de que tenemos que incidir muchos más en las características de las formas de acceso al cabildo o en los procesos de enajenación y patrimonialización de las prebendas. A día de hoy sabemos que determinadas dinastías, como los Posse de Soto, los Astorga o los Mendoza Caamaño, entre otros, tuvieron en sus manos diferentes dignidades en la primera mitad del xviII, pero una visión más amplia cronológicamente nos permitirá afirmar o desmentir si la patrimonialización de estos beneficios en el seno familiar se amplía a toda la centuria, para ello debemos avanzar en la reconstrucción genealógica.

Por lo que respecta al cabildo de Orense, siendo más pequeño, también estuvo interconectado con otras instituciones del noroeste peninsular y ocupó un papel central en las estrategias de promoción social de los grupos intermedios de la zona. Con todo, aún quedan aspectos por aclarar. En la actualidad nuestra investigación está centrada en otra de las instituciones de poder de la ciudad orensana, el concejo. Pero se hace necesario seguir profundizando en todas las demás para poder evaluar en su justa medida las relaciones que se establecieron. Especialmente, en la figura del obispo como actor importante en la dinámica capitular. Del mismo modo, futuras investigaciones nos permitirán comprobar el alcance geográfico de las redes que se establecieron y la eficacia de las mismas.

(C) Ediciones Universidad de Salamanca / ®@ Stud. his., H. ${ }^{a}$ mod., 39, n. 1 (2017), pp. 403-449 
MARÍA SEIJAS MONTERO Y LAURA RODICIO PEREIRA

LOS CABILDOS CATEDRALICIOS DE SANTIAGO Y ORENSE EN EL REINADO DE FELIPE V: ALGUNOS RESULTADOS

\section{APÉNDICE}

\section{SUCESIÓN EN LAS DIGNIDADES DE LA CATEDRAL DE SANTIAGO DE COMPOSTELA (1700-1750) $)^{59}$}

\begin{tabular}{|c|c|}
\hline Nombre & Período EN EL CARgo \\
\hline \multicolumn{2}{|l|}{ DEÁN } \\
\hline 1. Fabián Pardiñas Villardefrancos & $1691-1703$ \\
\hline 2. Lope de Omaña Uría & $1704-1707$ \\
\hline 3. Lope Manuel Baltasar de Omaña Queipo de Llano & $1708-1710$ \\
\hline 4. Francisco Pedro Jacinto Verdugo Martínez & $1713-1716$ \\
\hline 5. Manuel Francisco Rodríguez de Castro & $1717-1747$ \\
\hline 6. Juan Bernabé Cornejo Sancho & $1747-1750$ \\
\hline \multicolumn{2}{|l|}{ CHANTRE } \\
\hline 1. Pantaleón de San Miguel Otero Pedriza y Miranda & $1699-1707$ \\
\hline 2. José Antonio Vázquez Jaspe Montenegro & $1708-1715$ \\
\hline 3. Andrés Benito Antonio Pablo de Gondar & $1716-1776$ \\
\hline \multicolumn{2}{|l|}{ ARCEDIANO DE NENDOS } \\
\hline 1. Alonso Bravo de Buiza & $<1680-1702$ \\
\hline 2. Manuel Salazar & $1702-1703$ \\
\hline 3. Juan Sánchez de Vaamonde y Andrade & $1703-1727$ \\
\hline 4. Francisco Jerónimo Cisneros y Sarmiento & $1727-1750$ \\
\hline \multicolumn{2}{|l|}{ ARCEDIANO DE CORNADO } \\
\hline 1. Ignacio Leal de Seronde & $1690-1714 ?$ \\
\hline 2. Gaspar Martínez de Narbona & $1714-1727 ?$ \\
\hline 3. Lorenzo de Zúñiga y Rivera & $1727-1729$ \\
\hline 4. Sebastián Antonio de Valdivia Vázquez y Quesada & $1731-1736$ \\
\hline 5. Juan Francisco Antonio Prado y Ulloa & $1742-1785$ \\
\hline
\end{tabular}

59. Las series incluyen los nombres de los titulares en la primera mitad del XVIII. En algunos casos iniciaron su mandato con posterioridad a los años ochenta del siglo XVII, momento en el que se inicia el análisis. Cuando la fecha va seguida de interrogación indica que es dudosa, si va precedida del signo < indica que tomó posesión con anterioridad a 1680, pero desconocemos la fecha exacta, y si lo hace del signo > que lo hizo después de 1750.

(C) Ediciones Universidad de Salamanca / ®@ Stud. his., H. ${ }^{a}$ mod., 39, n. 1 (2017), pp. 403-449 
MARÍA SEIJAS MONTERO Y LAURA RODICIO PEREIRA

LOS CABILDOS CATEDRALICIOS DE SANTIAGO Y ORENSE EN EL REINADO DE FELIPE V: ALGUNOS RESULTADOS

\begin{tabular}{|c|c|}
\hline NoмвRE & Período en EL CARgo \\
\hline \multicolumn{2}{|l|}{ ARCEDIANO DE TRASTÁMARA } \\
\hline 1. Baltasar Mendoza Caamaño y Sotomayor & $1685-1703$ \\
\hline $\begin{array}{l}\text { 2. Álvaro Eugenio Antonio Benito Mauro de Mendoza Caamaño y } \\
\text { Sotomayor }\end{array}$ & $1703-1761$ \\
\hline \multicolumn{2}{|l|}{ ARCEDIANO DE SALNÉS } \\
\hline 1. Juan de Llanos y Astorga del Castillo & $<1680-1724$ \\
\hline 2. Juan José Armesto y Astorga & $1724-1752$ \\
\hline \multicolumn{2}{|l|}{ ARCEDIANO DE REINA } \\
\hline 1. Andrés José de Pedrajas Jurado & $1695-1707$ \\
\hline 2. Pedro Antonio José Posse de Soto y Gesto & $1709-1735$ \\
\hline 3. Gregorio José Antonio Posse de Soto & $1735-1755$ \\
\hline \multicolumn{2}{|l|}{ ARCEDIANO DE SANTIAGO } \\
\hline 1. Miguel del Olmo y Manrique de la Riba & $1697-1707$ \\
\hline 2. Vidal Marín de las Higueras & $1708-1710$ \\
\hline 3. Juan Correa Mendoza Sotomayor & $1710-1719$ \\
\hline 4. Baltasar Pedro de Frías Haro de la Vega & $1719-1743$ \\
\hline 5. José Miguel de Linares Morales & $1743-1767$ \\
\hline \multicolumn{2}{|l|}{ ARCEDIANO DE LUOU } \\
\hline 1. José López Andiano y Silva & $<1680-1705$ \\
\hline 2. Andrés Vilariño Segade & $1705-1712$ \\
\hline 3. Luís José Suárez de Bustamante y Recas & $1713-1715$ \\
\hline 4. Pedro Pablo Bartolomé Curiel y Luna & $1718-1727 ?$ \\
\hline 5. Francisco Antonio Espinosa de los Monteros & $1727-1750$ \\
\hline 6. Vicente Juan Antonio de Neira Tenreiro y Montenegro & $1750-1786$ \\
\hline \multicolumn{2}{|l|}{ TESOREROS } \\
\hline 1. Gregorio San Mamed de la Peña y Montaos & $1695-1718$ \\
\hline 2. Alonso Angueira y San Mamed & $1718-1725$ \\
\hline 3. Antonio Benito Jacobo Guiráldez y Ordoñez & $1725-1741$ \\
\hline 4. Toribio del Campillo y Cosío & $1742-1782$ \\
\hline \multicolumn{2}{|l|}{ MAESTRESCUELAS } \\
\hline 1. Andrés Espino y Andrade & $1696-1730$ \\
\hline 2. Diego Juan Francisco Antonio Vicente de Ulloa Alfonso Flórez & $1733-1764$ \\
\hline
\end{tabular}

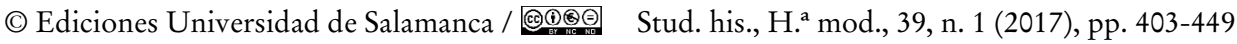


MARÍA SEIJAS MONTERO Y LAURA RODICIO PEREIRA

LOS CABILDOS CATEDRALICIOS DE SANTIAGO Y ORENSE EN EL REINADO DE FELIPE V: ALGUNOS RESULTADOS

\begin{tabular}{|c|c|}
\hline NOMbre & PERÍODO EN EL CARGO \\
\hline \multicolumn{2}{|l|}{ PRIOR DE SAR } \\
\hline 1. Pedro Portocarrero y Guzmán & $1692-1708$ \\
\hline 2. Carlos Juan Francisco de Borja Ponce de León y Centellas & $1708-1733$ \\
\hline 3. Manuel Juan Fernando Pérez de Guzmán el Bueno & $1734->1750$ \\
\hline \multicolumn{2}{|l|}{ PRIOR DE SANTIAGO } \\
\hline 1. José López Varela de Basadre & $1689-1713$ \\
\hline 2. Juan Francisco Simeón Gonzalo Vallo de Porras & $1713-1753$ \\
\hline \multicolumn{2}{|l|}{ CARDENAL MAYOR } \\
\hline 1. Francisco Pedro Jacinto Verdugo Martínez & $1695-1702$ \\
\hline 2. José Antonio Vázquez Jaspe Montenegro & $1702-1702$ \\
\hline 3. Francisco Pedro Jacinto Verdugo Martínez & $1702-1713$ \\
\hline 4. Pedro Antonio de Riaño de Malla & $1713-1729$ \\
\hline 5. Ignacio Bernardo de Pazo y Torre & $1729-1777$ \\
\hline \multicolumn{2}{|l|}{ CARDENALÍA 1} \\
\hline 1. Manuel de Silva Basurto & $1677-1701$ \\
\hline 2. Juan Antonio Peña Montalvo León y Luna & $1702-1710$ \\
\hline 3. Pedro Atanasio de Cabrera y Luna & $1710-1723$ \\
\hline 4. Benito Díaz de Castro y Pazos & $1723-1736$ \\
\hline 5. Francisco Antonio de Bezí y Yermo & $1736-1775$ \\
\hline \multicolumn{2}{|l|}{ CARDENALÍA 2} \\
\hline 1. Gómez Benito Ojea y Ulloa & $1690-1703$ \\
\hline 2. Antonio Mella y Varela & $1704-1748$ \\
\hline 3. Francisco de Mella Varela & $1748-1754$ \\
\hline \multicolumn{2}{|l|}{ CARDENALÍA 3} \\
\hline 1. Rodrigo Antonio de Romay y Sotomayor & $1690-1707$ \\
\hline 2. Manuel Pérez de Villanueva y Salazar & $1707-1731$ \\
\hline 3. Francisco Silvestre Bernardo de Salazar y Vega & $1731-1742$ \\
\hline 4. Felipe Jacobo Nicolás de la Vega y Calo Vallo de Porras & $1742-1787$ \\
\hline \multicolumn{2}{|l|}{ CARDENALÍA 4} \\
\hline 1. Luis Francisco Bermúdez de Castro & $1699-1727$ \\
\hline 2. José Francisco Bermúdez de Castro y Andrade & $1727-1752$ \\
\hline
\end{tabular}

(C) Ediciones Universidad de Salamanca / ⿶@@ Stud. his., H. ${ }^{a}$ mod., 39, n. 1 (2017), pp. 403-449 
MARÍA SEIJAS MONTERO Y LAURA RODICIO PEREIRA

LOS CABILDOS CATEDRALICIOS DE SANTIAGO Y ORENSE EN EL REINADO DE FELIPE V: ALGUNOS RESULTADOS

\begin{tabular}{|l|c|}
\hline \multicolumn{1}{|c|}{ Nombre } & Período en el CARgo \\
\hline CARDENALÍA 5 & $1696-1708$ \\
\hline 1. Antonio Manuel de Mella y Villar & $1710-1730$ \\
\hline 2. Diego Vázquez de Castro & $1731-1763$ \\
\hline 3. Ignacio de Mella Varela & $1694-1700$ \\
\hline CARDENALÍA 6 & $1700-1725$ \\
\hline 1. Manuel González Campos & $1725-1747$ \\
\hline 2. Gabriel de la Huerta y Posada & $1747-1751$ \\
\hline 3. Juan Antonio de la Cuesta y Huerta & \\
\hline 4. Policarpo de Mendoza Rodrigo &
\end{tabular}

Fuente: Actas Capitulares, Libros de posesiones y muertes (ss. XVII-XVIII), Pte. Sign., s.f.; Posesiones y Vacantes (XVIII-XIX), Pte. Sign y Dotaciones personales y gastos de culto. Relaciones de personal de la S.I. (1705-1870), ACS, IG 346.

\section{SUCESIÓN EN LAS CANONJÍAS DE OFICIO \\ DE LA CATEDRAL DE SANTIAGO DE COMPOSTELA (1700-1750)}

\begin{tabular}{|c|c|}
\hline Nombre & Período EN EL CARgo \\
\hline \multicolumn{2}{|l|}{ CANONJÍA DOCTORAL } \\
\hline 1. Manuel Granado Catalán & $1685-1714$ \\
\hline 2. Pedro Freire de Andrade & $1715-1734$ \\
\hline 3. Bartolomé Rajoy y Losada & $1734-1750$ \\
\hline \multicolumn{2}{|l|}{ CANONJÍA LECTORAL DE DECRETOS } \\
\hline 1. José Antonio Vázquez Jaspe Montenegro & $1694-1703$ \\
\hline 2. Miguel Jerónimo de Millara Montenegro & $1703-1717$ \\
\hline 3. Pedro Pablo Bartolomé Curiel y Luna & $1718-1726 ?$ \\
\hline 4. Benito Estévez de Castro & $1726-1759$ \\
\hline \multicolumn{2}{|l|}{ CANONJÍA LECTORAL DE SAGRADA ESCRITURA } \\
\hline 1. Jacinto Caamaño y Somoza & $1698-1701$ \\
\hline 2. José Francisco Bermúdez de Mandía & $1702-1729$ \\
\hline 3. Diego Díez Coronel & $1730-1739$ \\
\hline 4. Andrés de Aguilar y Herce & $1740-1747$ \\
\hline 5. Miguel Antonio Ambrosio Montes y Piñeiro & $1748-1782$ \\
\hline
\end{tabular}

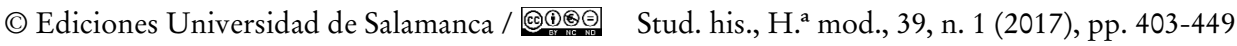


MARÍA SEIJAS MONTERO Y LAURA RODICIO PEREIRA

LOS CABILDOS CATEDRALICIOS DE SANTIAGO Y ORENSE EN EL REINADO DE FELIPE V: ALGUNOS RESULTADOS

\begin{tabular}{|c|c|}
\hline Nombre & Período en EL CARgo \\
\hline \multicolumn{2}{|l|}{ CANONJÍA MAGISTRAL } \\
\hline 1. Eliseo Zúñiga Villamaría & $1680-1710$ \\
\hline 2. Diego Jacinto Romero de Moscoso & $1711-1718$ \\
\hline 3. Lorenzo Bernardo Facundo José Moscoso y Romay & $1718-1728$ \\
\hline 4. José Ignacio Varela Vázquez y Bermúdez & $1728-1740$ \\
\hline 5. José Francisco de Losada y Quiroga & $1741-1761$ \\
\hline \multicolumn{2}{|l|}{ CANONJÍA PENITENCIARIA } \\
\hline 1. Juan Torrado Mariño y Ribas & $1696-1709$ \\
\hline 2. Pedro Gómez Prieto & $1710-1717$ \\
\hline 3. Juan Abello Castrillón & $1730-1731$ \\
\hline 4. José Antonio de Goiri y Barúa & $1731-1750$ \\
\hline 5. Carlos Antonio Riomol y Quiroga & $1750-1752$ \\
\hline \multicolumn{2}{|l|}{ CANONJÍA DE MAESTRO DE CAPILLA } \\
\hline 1. José de Vaquedano & $1681-1710$ \\
\hline 2. Miguel Ambiela & $1710-1710$ \\
\hline 3. Antonio Francisco de Yanguas Moreno & $1710-1718$ \\
\hline 4. Diego José de las Muelas Cardo & $1719-1723$ \\
\hline 5. Pedro Rodrigo Gómez & $1724-1744$ \\
\hline 6. Pedro Cifuentes Mazo & $1745-1768$ \\
\hline
\end{tabular}

Fuente: Actas Capitulares, Libros de posesiones y muertes (ss. XVII-XVIII), Pte. Sign. s/f; Posesiones y Vacantes (XVIII-XIX), Pte. Sign y Dotaciones personales y gastos de culto. Relaciones de personal de la S.I. (1705-1870), ACS, IG 346.

\section{SUCESIÓN DE LOS CANÓNIGOS ATITULADOS DE LA CATEDRAL DE SANTIAGO DE COMPOSTELA (1700-1750)}

\begin{tabular}{|l|c|}
\hline \multicolumn{1}{|c|}{ Nombre } & Período en El CARGo \\
\hline CANONJíA 1 & $1678-1710$ \\
\hline 1. Manuel Márquez de San Martín & $1710-1732$ \\
\hline 2. Juan Antonio de Urquiola y Gainza & $1733-1775$ \\
\hline 3. Tomás José Nicolás Portillo y Yermo & \\
\hline
\end{tabular}

(C) Ediciones Universidad de Salamanca / ⿶@@ Stud. his., H. ${ }^{a}$ mod., 39, n. 1 (2017), pp. 403-449 
MARÍA SEIJAS MONTERO Y LAURA RODICIO PEREIRA

LOS CABILDOS CATEDRALICIOS DE SANTIAGO Y ORENSE EN EL REINADO DE FELIPE V: ALGUNOS RESULTADOS

\begin{tabular}{|c|c|}
\hline Nombre & Período en el cargo \\
\hline \multicolumn{2}{|l|}{ CANONJÍA 2} \\
\hline 1. Mateo Riobó y Seixas & $1687-1700$ \\
\hline 2. Antonio de Senlle Vázquez y Figueroa & $1701-1739$ \\
\hline 3. Luís Bernardo Guiráldez Romero y Ordóñez & $1739-1783$ \\
\hline \multicolumn{2}{|l|}{ CANONJÍA 3} \\
\hline 1. Miguel del Olmo y Manrique de la Riba & $1697-1706$ \\
\hline 2. Lorenzo Ruiz de Sarmentera & $1706-1730$ \\
\hline 3. Diego Jacinto Quiroga Valcarce & $1732-1757$ \\
\hline \multicolumn{2}{|l|}{ CANONJÍA 4} \\
\hline 1. Antonio Jacinto Fariña de la Concha & $1683-1710$ \\
\hline 2. Ignacio Antonio Fariña y Romay & $1710-1728$ \\
\hline 3. José Antonio Manuel Fariña y Taboada & $1728-1762$ \\
\hline \multicolumn{2}{|l|}{ CANONJÍA 5} \\
\hline 1. Jacinto Lorenzo de Bañales y Moscoso & $1694-1710$ \\
\hline 2. Juan de Bantiñán y Orgeira & $1715-1731$ \\
\hline 3. Francisco Miguel Barona Maldonado & $1731-1742$ \\
\hline 4. José Miguel de Linares Morales & $1743-1743$ \\
\hline 5. José Antonio Félix Jiménez Bravo & $1743-1777$ \\
\hline \multicolumn{2}{|l|}{ CANONJÍA 6} \\
\hline 1. Juan Antonio de Somoza y Caamaño Montenegro & $1688-1712$ \\
\hline 2. Felipe Diego de Santa María y Salazar & $1712-1721$ \\
\hline 3. Julián Tomás de Santa María y Salazar & $1721-1747$ \\
\hline 4. Vicente Gil Taboada y Teijeiro & $1748-1780$ \\
\hline \multicolumn{2}{|l|}{ CANONJÍA 7} \\
\hline 1. Ángel Blanco de Salcedo & $1697-1710$ \\
\hline 2. Juan Antonio de Riaño de Malla & $1712-1726$ \\
\hline 3. Francisco Antonio Espinosa de los Monteros & $1727-1750$ \\
\hline 4. Vicente Juan Antonio de Neira Tenreiro y Montenegro & $1750-1787 ?$ \\
\hline \multicolumn{2}{|l|}{ CANONJÍA 8} \\
\hline 1. Antonio Bernardo González de Zaldívar & $1692-1708$ \\
\hline 2. Antonio Romero de Leis y Caldas & $1713-1729$ \\
\hline 3. Ambrosio Mallón Blanco & $1730-1743$ \\
\hline 4. José Santos de Taranco Otáñez & $1743-1751$ \\
\hline
\end{tabular}

(C) Ediciones Universidad de Salamanca / ⿶@@ Stud. his., H. ${ }^{a}$ mod., 39, n. 1 (2017), pp. 403-449 
MARÍA SEIJAS MONTERO Y LAURA RODICIO PEREIRA

LOS CABILDOS CATEDRALICIOS DE SANTIAGO Y ORENSE EN EL REINADO DE FELIPE V: ALGUNOS RESULTADOS

\begin{tabular}{|c|c|}
\hline Nombre & Período en el cargo \\
\hline \multicolumn{2}{|l|}{ CANONJÍA 9} \\
\hline 1. Andrés Ruiz Ruiz & $1694-1720$ \\
\hline 2. Andrés Ruiz Gallo «el Mozo» & $1720-1722$ \\
\hline 3. Manuel Antonio Posse de Soto y Gesto & $1723-1763$ \\
\hline \multicolumn{2}{|l|}{ CANONJÍA 10} \\
\hline 1. Urbán García Garamato & $1680-1709$ \\
\hline 2. Baltasar Benito Llorente de Castro & $1709-1746$ \\
\hline 3. José Ramón Antonio Hernández de Uzal & $1747-1770$ \\
\hline \multicolumn{2}{|l|}{ CANONJÍA 11} \\
\hline 1. José Vázquez Míguez Ribadas & $1699-1718$ \\
\hline 2. Manuel de la Cruz Rivera y Sotomayor & $1718-1727$ \\
\hline 3. José Baeza & $1727-1729$ \\
\hline 4. José Antonio Sánchez del Pino & $1729-1761$ \\
\hline \multicolumn{2}{|l|}{ CANONJÍA 12} \\
\hline 1. Pedro Francisco de Olaegui y Sarria & $1680-1700$ \\
\hline 2. Manuel Silvestre de Yanguas Morales & 1701-1749 \\
\hline 3. Domingo Ignacio de Santa María y San Martín & $1749-1758$ \\
\hline \multicolumn{2}{|l|}{ CANONJÍA 13} \\
\hline 1. Andrés Mateo Santos de Herce & $1686-1710$ \\
\hline 2. José Damaso de Parga y Basadre & $1712-1733$ \\
\hline 3. Fructuoso Becerra de Moscoso & $1733-1734$ \\
\hline 4. Álvaro Froilán Romero Figueroa & $1734-1762$ \\
\hline \multicolumn{2}{|l|}{ CANONJÍA 14} \\
\hline 1. Andrés Alfonso de Ovalle y Campillo & $1696-1737$ \\
\hline 2. José Sánchez Calvete & $1738-1775$ \\
\hline \multicolumn{2}{|l|}{ CANONJÍA 15} \\
\hline 1. Diego José Piñeiro de Ulloa & $1692-1710$ \\
\hline 2. Juan Antonio de Castro Romero & $1713-1737$ \\
\hline 3. Juan Francisco Caamaño Taboada & $1742-1767$ \\
\hline \multicolumn{2}{|l|}{ CANONJÍA 16} \\
\hline 1. Inocencio Manuel Guiráldez de Aguiar y Caamaño & $1697-1714$ \\
\hline 2. José Joaquín Herrán y Zarate & $1714-1754$ \\
\hline
\end{tabular}

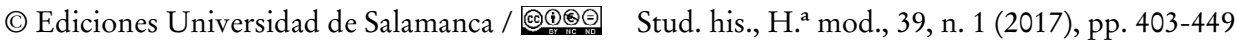


MARÍA SEIJAS MONTERO Y LAURA RODICIO PEREIRA

LOS CABILDOS CATEDRALICIOS DE SANTIAGO Y ORENSE EN EL REINADO DE FELIPE V: ALGUNOS RESULTADOS

\begin{tabular}{|c|c|}
\hline Nombre & Período en el CARgo \\
\hline \multicolumn{2}{|l|}{ CANONJÍA 17} \\
\hline 1. Pedro de Navia Mariño & $<1680-1702$ \\
\hline 2. José Varela Basadre & $1702-1713$ \\
\hline 3. Juan Antonio Varela Mariño & $1713-1742$ \\
\hline 4. Francisco Jerónimo Cisneros y Sarmiento & $1742-1750$ \\
\hline \multicolumn{2}{|l|}{ CANONJÍA 18} \\
\hline 1. Antonio Vázquez Bermúdez & $1681-1724$ \\
\hline 2. Cayetano Gil Taboada & $1725-1736$ \\
\hline 3. Juan Antonio José Martínez Carranza & $1736-1737$ \\
\hline 4. Antonio Marroquín Montehermoso y Recalde & $1737-1781$ \\
\hline \multicolumn{2}{|l|}{ CANONJÍA 19} \\
\hline 1. Juan Martín Casado & $1700-1708$ \\
\hline 2. José Benito Manuel Posse de Soto y Gesto & $1709-1744$ \\
\hline 3. Joaquín Fernádez Portocarrero & $1744-1745$ \\
\hline 4. Juan Bautista de Briongos Hernando & $1746-1766$ \\
\hline \multicolumn{2}{|l|}{ CANONJÍA 20} \\
\hline 1. Juan de Leis Andrade Moscoso y Ponte & $1693-1710$ \\
\hline 2. Fabián Antonio de Pardiñas Villardefrancos Varela Becerra & $1713-1731$ \\
\hline 3. Agustín de Vaamonde Varela y Valenzuela & $1732-1734$ \\
\hline 4. Ignacio Carlos Benito Fernando Osorio y Omaña & $1737-1748$ \\
\hline 5. Juan Eligio Sicilio de la Cárcel Reinoso & $1749-1777$ \\
\hline \multicolumn{2}{|l|}{ CANONJÍA 21} \\
\hline 1. Luís de Pazos y Gómez & $1690-1700$ \\
\hline 2. Andrés José de Pedrajas Jurado & $1700-1707$ \\
\hline 3. Fernando Antonio de Carantoña y Mendoza & $1707-1712$ \\
\hline 4. Lucas Antonio Ferreiro de la Torre & $1712-1738$ \\
\hline 5. Antonio José de la Torre y Gil & $1738-1759$ \\
\hline \multicolumn{2}{|l|}{ CANONJÍA 22} \\
\hline 1. Juan de Castro y Caamaño & $1704-1730$ \\
\hline 2. Blas Manuel Parcero y Lira & $1730-1738$ \\
\hline 3. Pedro Fole de Navia & $1739-1776$ \\
\hline
\end{tabular}

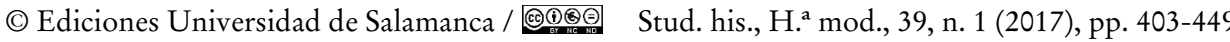


MARÍA SEIJAS MONTERO Y LAURA RODICIO PEREIRA

LOS CABILDOS CATEDRALICIOS DE SANTIAGO Y ORENSE EN EL REINADO DE FELIPE V: ALGUNOS RESULTADOS

\begin{tabular}{|c|c|}
\hline Nombre & Período en el cargo \\
\hline \multicolumn{2}{|l|}{ CANONJÍA 23} \\
\hline 1. Tomás Pardo Ribadeneira & $1686-1713$ \\
\hline 2. Benito Díaz de Castro y Pazos & $1714-1723$ \\
\hline 3. Pedro Atanasio de Cabrera y Luna & $1723-1749$ \\
\hline 4. Domingo Cayetano Estévez de Castro & $1749-1753$ \\
\hline \multicolumn{2}{|l|}{ CANONJÍA 24} \\
\hline 1. Juan Antonio Carantoña da Costa & $1679-1713$ \\
\hline 2. Pablo Valladares Somoza & $1713-1740$ \\
\hline 3. Bernardo Francisco Valladares Louzao & $1740-1748$ \\
\hline 4. Juan Antonio Valladares y Somoza & $1749-1768$ \\
\hline \multicolumn{2}{|l|}{ CANONJÍA 25} \\
\hline 1. Antonio García Argüelles & $1685-1732$ \\
\hline 2. José Domingo de Valdivieso Sánchez & $1733-1779$ \\
\hline \multicolumn{2}{|l|}{ CANONJÍA 26} \\
\hline 1. José López Andiano y Silva & $<1680-1705$ \\
\hline 2. José Viguera y González & $1705-1740$ \\
\hline 3. Francisco de Paula Antonio Prado Portocarrero y Ronquillo & $1740-1741$ \\
\hline 4. Esteban Granado Catalán & $1741-1753$ \\
\hline \multicolumn{2}{|l|}{ CANONJÍA 27} \\
\hline 1. Andrés Vilariño y Segade & $1695-1712$ \\
\hline 2. Luís José Súarez de Bustamante & $1713-1715$ \\
\hline 3. Juan Francisco Feliciano de Fernández de Talavera & $1716-1717$ \\
\hline 4. Jerónimo Antonio de Barreda y Yebra & $1717-1758$ \\
\hline \multicolumn{2}{|l|}{ CANONJÍA 28} \\
\hline 1. Alonso Bravo de Buiza & $1662-1702$ \\
\hline 2. Manuel Pérez de Villanueva y Salazar & $1702-1702$ \\
\hline 3. Juan Sánchez de Vaamonde y Andrade & $1703-1729$ \\
\hline 4. Jacinto Antonio Gómez Pereira de Leis y Ocampo Villarprego & $1729-1757$ \\
\hline
\end{tabular}

Fuente: Actas Capitulares, Libros de posesiones y muertes (ss. XVII-XVIII), Pte. Sign. s/f; Posesiones y Vacantes (XVIII-XIX), Pte. Sign y Dotaciones personales y gastos de culto. Relaciones de personal de la S.I. (1705-1870), ACS, IG 346.

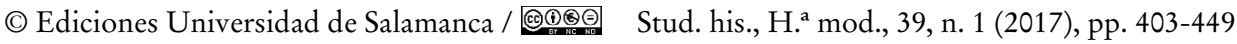


MARÍA SEIJAS MONTERO Y LAURA RODICIO PEREIRA

LOS CABILDOS CATEDRALICIOS DE SANTIAGO Y ORENSE EN EL REINADO DE FELIPE V: ALGUNOS RESULTADOS

\section{SUCESIÓN DE LOS RACIONEROS ATITULADOS DE LA CATEDRAL DE SANTIAGO DE COMPOSTELA (1700-1750)}

\begin{tabular}{|c|c|}
\hline Nombre & Período en EL CARgo \\
\hline \multicolumn{2}{|l|}{ RACIÓN 1} \\
\hline 1. Francisco García Abadiano & $1679-1722$ \\
\hline 2. Manuel García Abadiano & $1722-1768$ \\
\hline \multicolumn{2}{|l|}{ RACIÓN 2} \\
\hline 1. Francisco Rodríguez de Armesto Pérez & $1683-1710$ \\
\hline 2. Juan de Yanguas Morales & $1710-1750$ \\
\hline 3. Diego Antonio Pereira y Moscoso & $1750-1787$ \\
\hline \multicolumn{2}{|l|}{ RACIÓN 3} \\
\hline 1. Alonso de Orgeira García & $1681-1727$ \\
\hline 2. Domingo García de Orgeira de Estúa & $1727-1740$ \\
\hline 3. Francisco Antonio de Bantiñán y Orgeira & $1740-1764$ \\
\hline \multicolumn{2}{|l|}{ RACIÓN 4} \\
\hline 1. Gabriel de la Huerta y Posada & $1696-1700$ \\
\hline 2. Juan Froilán Varela y Luna & $1700-1703$ \\
\hline 3. Pedro de Mahía y Lago & $1703-1724$ \\
\hline 4. Miguel Pereira y Mahía & $1724-1745$ \\
\hline 5. Miguel José Pereira Mato & $1745-1784$ \\
\hline \multicolumn{2}{|l|}{ RACIÓN 5} \\
\hline 1. Lorenzo Ruiz Sarmenteira & $1698-1705$ \\
\hline 2. Bernardo Fernández de Araújo & $1705-1714$ \\
\hline 3. Benito de Carvajal y Carballo & $1714-1755 ?$ \\
\hline \multicolumn{2}{|l|}{ RACIÓN 6} \\
\hline 1. José San Miguel Otero Pedriza y Miranda & $1686-1713$ \\
\hline 2. Salvador Francisco de Fernández de Bastavales y Talavera & $1715-1750$ \\
\hline 3. Francisco Antonio Pedro Nolasco Hernández de Uzal & $1750-1786$ \\
\hline \multicolumn{2}{|l|}{ RACIÓN 7} \\
\hline 1. Antonio Fernández de Nogueira & $1698-1748$ \\
\hline 2. Pedro Andrés Labandeira Mesías & $1748-1781$ \\
\hline
\end{tabular}

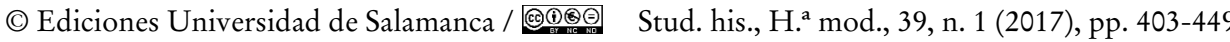


MARÍA SEIJAS MONTERO Y LAURA RODICIO PEREIRA

LOS CABILDOS CATEDRALICIOS DE SANTIAGO Y ORENSE EN EL REINADO DE FELIPE V: ALGUNOS RESULTADOS

\begin{tabular}{|c|c|}
\hline NombRe & Período EN EL CARgo \\
\hline \multicolumn{2}{|l|}{ RACIÓN 8} \\
\hline 1. Juan Martín Casado & $1687-1700$ \\
\hline 2. Manuel Pérez de Villanueva y Salazar & $1700-1702$ \\
\hline 3. Francisco de la Huerta Posada & $1702-1702$ \\
\hline 4. Manuel Pérez de Villanueva y Salazar & $1702-1707$ \\
\hline 5. Juan Antonio de Urquiola y Gainza & $1707-1710$ \\
\hline 6. Pedro de Barcia y Araújo & $1710-1710$ \\
\hline 7. Esteban Granado Catalán & $1710-1741$ \\
\hline 8. Antonio Clemente de Ponte y Andrade & $1741-1758$ \\
\hline \multicolumn{2}{|l|}{ RACIÓN 9} \\
\hline 1. Juan Matías Mariño de Sotomayor & $1695-1709$ \\
\hline 2. Pedro Atanasio Cabrera y Luna & $1709-1710$ \\
\hline 3. Juan Bernardo Serrano y Montalvo & $1710-1711$ \\
\hline 4. Andrés Jerónimo de Porras y Gayoso & $1711-1741$ \\
\hline 5. Florencio Antonio de Soto y Carballido & $1741-1769$ \\
\hline
\end{tabular}

Fuente: Actas Capitulares, Libros de posesiones y muertes (ss. XVII-XVIII), Pte. Sign. s/f; Posesiones y Vacantes (XVIII-XIX), Pte. Sign y Dotaciones personales y gastos de culto. Relaciones de personal de la S.I. (1705-1870), ACS, IG 346.

5. SUCESIÓN EN LAS DIGNIDADES

DE LA CATEDRAL DE ORENSE (1700-1750)

\begin{tabular}{|l|c|}
\hline \multicolumn{1}{|c|}{ Nombre } & Período en el CARGO \\
\hline DEÁN & $1700-1715$ \\
\hline 1. Francisco de la Pena Losada & $1715-1743$ \\
\hline 2. Benito Ventura Guntín Pillado y Luaces & $1743-1769$ \\
\hline 3. José Benito Álvarez Guntín & \\
\hline CHANTRE & $1700-1722$ \\
\hline 1. Miguel Cornejo y Moreto & $1723-1723$ \\
\hline 2. Juan Muñoz y Peralta & $1723-1733$ \\
\hline 3. Pedro Puga & $1733-1793$ \\
\hline 4. Santiago Mercado y Monroy & \\
\hline
\end{tabular}

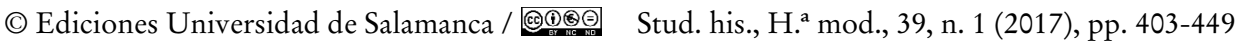


MARÍA SEIJAS MONTERO Y LAURA RODICIO PEREIRA

LOS CABILDOS CATEDRALICIOS DE SANTIAGO Y ORENSE EN EL REINADO DE FELIPE V: ALGUNOS RESULTADOS

\begin{tabular}{|c|c|}
\hline Nombre & Período en EL CARgo \\
\hline \multicolumn{2}{|l|}{ TESORERO } \\
\hline 1. Tomás Espinosa & $1700-1735$ \\
\hline 2. José Fernando Páramo y Montenegro & $1737-1769$ \\
\hline \multicolumn{2}{|l|}{ MAESTREESCUELA } \\
\hline 1. Antonio Castell Ros de Medrano & $1700-1729$ \\
\hline 2. Joaquín Ros & $1729-1748$ \\
\hline 3. Blas Rivera & $1748-1762$ \\
\hline \multicolumn{2}{|l|}{ ARCEDIANO DE CASTELA } \\
\hline 1. Domingo Fernández Veloso & $1698-1728$ \\
\hline 2. Benito Valdés & $1728-1750$ \\
\hline 3. José Benito Vázquez Romay & $1750-1775$ \\
\hline \multicolumn{2}{|l|}{ ARCEDIANO DE BARONCELI } \\
\hline 1. José Cornejo & $1706-1723$ \\
\hline 2. Juan Muñoz y Peralta & $1723-1735$ \\
\hline 3. Francisco Freire & $1735-1771$ \\
\hline \multicolumn{2}{|l|}{ ARCEDIANO DE BUBAL } \\
\hline 1. Juan Antonio Fernández de Prado & $1700-1730$ \\
\hline 2. Pedro Fernández de San Pedro & $1730-1749$ \\
\hline 3. Pedro Atanasio Blanco & $1749-1758$ \\
\hline \multicolumn{2}{|l|}{ ARCEDIANO DE LIMIA } \\
\hline 1. Benito de Lemos Bolaño & $1689-1702$ \\
\hline 2. Vicente Cedrón y Valcárcel & $1702-1751$ \\
\hline \multicolumn{2}{|l|}{ ARCEDIANO DE OURENSE } \\
\hline 1. José Feijoo García & $1700-1714$ \\
\hline 2. Rodrigo Ulloa & $1714-1731$ \\
\hline 3. Pedro Fontanilla & $1731-1742$ \\
\hline 4. Pedro Martínez de Arce & $1743-1757$ \\
\hline \multicolumn{2}{|l|}{ ABAD DE LA TRINIDAD } \\
\hline 1. Pedro Aranda Quintanilla y Mendoza & $1674-1712$ \\
\hline 2. Berenguer Daoiz & 1718 \\
\hline 3. José Prieto & $1726-1731$ \\
\hline
\end{tabular}

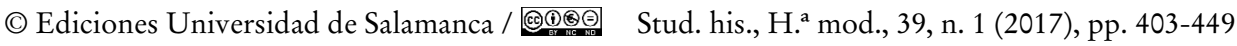


MARÍA SEIJAS MONTERO Y LAURA RODICIO PEREIRA

LOS CABILDOS CATEDRALICIOS DE SANTIAGO Y ORENSE EN EL REINADO DE FELIPE V: ALGUNOS RESULTADOS

\begin{tabular}{|l|c|}
\hline \multicolumn{1}{|c|}{ Nombre } & PERÍODO EN EL CARGO \\
\hline 4. Tomás Sarmiento de la Coba & $1732-1735$ \\
\hline 5. Diego García de Calderón & $1735-1744$ \\
\hline 6. Francisco Vélez Frías & 1745 \\
\hline 7. Manuel Figueroa & 1747 \\
\hline 8. Basilio Antonio Rávago & 1750 \\
\hline ABAD DE CELANOVA & \\
\hline 1. Manuel Pimentel & $1697-1701$ \\
\hline 2. Benito de Pazos & $1700-1705$ \\
\hline 3. José Sotelo & $1705-1709$ \\
\hline 4. José Arriaga & $1709-1713$ \\
\hline 5. José Sotelo & $1713-1717$ \\
\hline 6. Antonio Leboso & $1717-1721$ \\
\hline 7. José Sotelo & $1721-1723$ \\
\hline 8. Pedro Blanco & $1723-1725$ \\
\hline 9. Juan de Villamarín & $1725-1729$ \\
\hline 10. Pedro Blanco & $1729-1733$ \\
\hline 11. Pablo Monroy & $1733-1734$ \\
\hline 12. Ruperto Carrasco & $1734-1737$ \\
\hline 13. Pedro Blanco & $1749-1741$ \\
\hline 14. Juan de Villamarin & \\
\hline 15. Benito Gesto & \\
\hline 16. Antonio Sanz & \\
\hline & \\
\hline
\end{tabular}

Fuente: ACO Actas Capitulares, Pte. Sign. Abad de la Trinidad: Barriocanal López, Y.: Hospital, igrexa e pazos da abadía da Santísima Trinidade. Orense, 2003. Abad de Celanova: Zaragoza I Pascual, E.: «Abadologio del monasterio de San Salvador de Celanova (Siglos X-XIX)», Compostellanum, 45, 1-2, 2000, pp. 81-100.

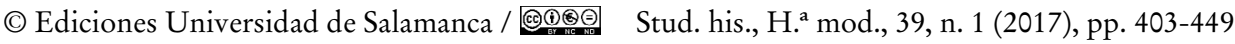


MARÍA SEIJAS MONTERO Y LAURA RODICIO PEREIRA

LOS CABILDOS CATEDRALICIOS DE SANTIAGO Y ORENSE EN EL REINADO DE FELIPE V: ALGUNOS RESULTADOS

\section{SUCESIÓN EN LAS CANONJÍAS DE OFICIO}

DE LA CATEDRAL DE ORENSE (1700-1750)

\begin{tabular}{|l|c|}
\hline \multicolumn{1}{|c|}{ NOMBRE } & PERÍODO EN EL CARGO \\
\hline CANONJÍA DOCTORAL & $1689-1708$ \\
\hline 1. Pedro Fernández de San Pedro & $1708-1709$ \\
\hline 2. Juan Sotelo Amoeiro & $1710-1724$ \\
\hline 3. José Carrasco & $1725-1730$ \\
\hline 4. Manuel Riobello & $1733-1751$ \\
\hline 5. Manuel Figueroa & \\
\hline CANONJíA LECTORAL & $1702-1706$ \\
\hline 1. Antonio Varela Figueroa & $1706-1714$ \\
\hline 2. José Prieto & $1714-1722$ \\
\hline 3. José Cornejo y Granados & $1722-1754$ \\
\hline 4. Alonso Rueda & $1719-1723$ \\
\hline CANONJíA MAGISTRAL & $1724-1726$ \\
\hline 1. García del Peco & $1726-1729$ \\
\hline 2. Ignacio Lilera & $1731-1765$ \\
\hline 3. Salvador Pose y Saavedra & $1707-1721$ \\
\hline 4. Lucas Vélez Moro & \\
\hline 5. Manuel Sanz de Velasco & $1700-1719$ \\
\hline CANONJíA PENITENCIARIA & \\
\hline 1. Francisco Osorio & \\
\hline 2. Miguel Horacio Piornedo y Aguiar & \\
\hline 3. Bartolomé Rajoy & \\
\hline 4. Diego López Gayoso & \\
\hline 5. José Yañez de Zúñiga & \\
\hline
\end{tabular}

Fuente: ACO Actas Capitulares, Pte. Sign.

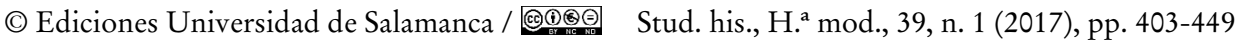


MARÍA SEIJAS MONTERO Y LAURA RODICIO PEREIRA

LOS CABILDOS CATEDRALICIOS DE SANTIAGO Y ORENSE EN EL REINADO DE FELIPE V: ALGUNOS RESULTADOS

\section{SUCESIÓN DE LOS CANÓNIGOS PRESBITERIALES \\ DE LA CATEDRAL DE ORENSE (1700-1750)}

\begin{tabular}{|c|c|}
\hline Nombre & Período EN EL CARgo \\
\hline \multicolumn{2}{|l|}{ CANONJÍA PRESBITERIAL 1} \\
\hline 1. José Jiménez & $1689-1702$ \\
\hline 2. Benito Vázquez Eraso & $1702-1719$ \\
\hline 3. Lorenzo Taranco y Musarieta & $1719-1720$ \\
\hline 4. Francisco Méndez Feijoo & $1720-1736$ \\
\hline 5. José Pérez Montero & $1736-1751$ \\
\hline \multicolumn{2}{|l|}{ CANONJÍA PRESBITERIAL 2} \\
\hline 1. Joaquín Ros & $1700-1748$ \\
\hline 2. Joaquín Pardiñas & $1748-1759$ \\
\hline \multicolumn{2}{|l|}{ CANONJÍA PRESBITERIAL 3} \\
\hline 1. Andrés Ruíz de Salamanca & $1689-1714$ \\
\hline 2. José Calpe Dobón & $1714-1762$ \\
\hline \multicolumn{2}{|l|}{ CANONJÍA PRESBITERIAL 4} \\
\hline 1. Benito Cid Fidalgo & $1689-1706$ \\
\hline 2. Benito Nogueira Cid & $1706-1756$ \\
\hline \multicolumn{2}{|l|}{ CANONJÍA PRESBITERIAL 5} \\
\hline 1. Agustín Cid & $1689-1703$ \\
\hline 2. Manuel Fernández Cevallos & $1703-1743$ \\
\hline 3. Mateo Ramos y Solís & $1748-1790$ \\
\hline \multicolumn{2}{|l|}{ CANONJÍA PRESBITERIAL 6} \\
\hline 1. Alonso de Ulloa Taboada & $1689-1730$ \\
\hline 2. Pedro Saco Taboada & $1730-1732$ \\
\hline 3. Julián Álvarez & $1732-1744$ \\
\hline 4. Miguel Armida y Martínez & $1744-1749$ \\
\hline 5. Manuel Antonio Tejada & $1750-1769$ \\
\hline \multicolumn{2}{|l|}{ CANONJÍA PRESBITERIAL 7} \\
\hline 1. Jacinto Suárez Cid & $1702-1736$ \\
\hline 2. Pedro Muñoz y Peralta & $1736-1766$ \\
\hline
\end{tabular}

(C) Ediciones Universidad de Salamanca / ®@ Stud. his., H. ${ }^{a}$ mod., 39, n. 1 (2017), pp. 403-449 
MARÍA SEIJAS MONTERO Y LAURA RODICIO PEREIRA

LOS CABILDOS CATEDRALICIOS DE SANTIAGO Y ORENSE EN EL REINADO DE FELIPE V: ALGUNOS RESULTADOS

\begin{tabular}{|l|c|}
\hline \multicolumn{1}{|c|}{ Nombre } & Período en EL CARgo \\
\hline CANONJÍA PRESBITERIAL 8 & $1700-1714$ \\
\hline 1. Isidro Balmaseda & $1714-1722$ \\
\hline 2. Francisco Álvarez & $1722-1735$ \\
\hline 3. Juan Muñoz y Peralta & $1735-1760$ \\
\hline 4. Martin Cardona & \\
\hline
\end{tabular}

Fuente: ACO, Actas Capitulares, Pte. Sign.

\section{SUCESIÓN DE LOS CANÓNIGOS SIMPLES}

DE LA CATEDRAL DE ORENSE (1700-1750)

\begin{tabular}{|l|c|}
\hline \multicolumn{1}{|c|}{ Nombre } & Período en EL CARGo \\
\hline CANONJíA 1 & $1689-1706$ \\
\hline 1. Rodrigo Verjano Gayoso & $1706-1722$ \\
\hline 2. José Cornejo y Granados & $1724-1766$ \\
\hline 3. Carlos Vázquez Trigo & $1689-1702$ \\
\hline CANONJÍA 2 & $1714-1742$ \\
\hline 1. Sebastián Verea & $1742-1794$ \\
\hline 2. José Pereira de Bóveda & \\
\hline 3. Benito Gallardo y Pereira & 1700 \\
\hline CANONJíA 3 & $1728-1732$ \\
\hline 1. Antonio Castel y Ros de Medrano & $1732-1770$ \\
\hline 2. Miguel Alfonso Yañez y Santa Cruz & \\
\hline 3. Francisco Sánchez Villamarín & $1689-1703$ \\
\hline CANONJÍA 4 & $1703-1715$ \\
\hline 1. Ignacio de Lemos & $1715-1720$ \\
\hline 2. Manuel García de Espinosa Sotelo & 1720 \\
\hline 3. Francisco Méndez Feijoo & $1725-1765$ \\
\hline 4. Lorenzo Taranco Musarieta & $1734-1758$ \\
\hline 5. Pedro Medela & \\
\hline CANONJíA 5 & $1799-1722$ \\
\hline 1. Miguel Cornejo y Moreto & \\
\hline 2. Pedro Puga & \\
\hline 3. Manuel Fernández de Prado & \\
\hline
\end{tabular}

(C) Ediciones Universidad de Salamanca / 요 Stud. his., H. ${ }^{a}$ mod., 39, n. 1 (2017), pp. 403-449 
MARÍA SEIJAS MONTERO Y LAURA RODICIO PEREIRA

LOS CABILDOS CATEDRALICIOS DE SANTIAGO Y ORENSE EN EL REINADO DE FELIPE V: ALGUNOS RESULTADOS

\begin{tabular}{|c|c|}
\hline Nombre & Período en EL CARgo \\
\hline \multicolumn{2}{|l|}{ CANONJÍA 6} \\
\hline 1. Francisco Villar y Toubes & $1698-1740$ \\
\hline 2. Benito de Cárdenas & $1740-1753$ \\
\hline \multicolumn{2}{|l|}{ CANONJÍA 7} \\
\hline 1. Juan Bartolomé Jiménez & $1701-1722$ \\
\hline 2. Francisco Nóvoa y Araujo & 1724 \\
\hline 3. Pedro de Seijas & $1750-1765$ \\
\hline \multicolumn{2}{|l|}{ CANONJÍA 8} \\
\hline 1. Felipe Parada & $1689-1724$ \\
\hline 2. Juan Antonio Parada & 1724 \\
\hline 3. Francisco Fermín Vergara & $1749-1765$ \\
\hline \multicolumn{2}{|l|}{ CANONJÍA 9} \\
\hline 1. Isidro de la Fuente & $1701-1714$ \\
\hline 2. Torivio de Arce Calderón & $1714-1748$ \\
\hline 3. Francisco Fermín de Vergara & $1749-1765$ \\
\hline \multicolumn{2}{|l|}{ CANONJÍA 10} \\
\hline 1. Luís de Ulloa & $1700-1711$ \\
\hline 2. Rodrigo de Ulloa & $1711-1714$ \\
\hline 3. José Feijoo García & $1714-1742$ \\
\hline 4. Domingo Blanco de Araujo & $1742-1748$ \\
\hline 5. Juan Antonio Rial de Castro & $1748-1774$ \\
\hline \multicolumn{2}{|l|}{ CANONJÍA 11} \\
\hline 1. Juan Sotelo y Amoeiro & $1704-1709$ \\
\hline 2. Antonio Sotelo y Amoeiro & $1711-1735$ \\
\hline 3. Diego Fole de Navia & $1739-1798$ \\
\hline \multicolumn{2}{|l|}{ CANONJÍA 12} \\
\hline 1. Francisco de Ponte & $1700-1715$ \\
\hline 2. Juan José Tejada Eiriz & $1720-1746$ \\
\hline 3. Manuel Antonio Tejada & $1746-1749$ \\
\hline 4. Miguel Armida y Martínez & $1749-1797$ \\
\hline
\end{tabular}

Fuente: ACO, Actas Capitulares, Pte. Sign.

(C) Ediciones Universidad de Salamanca / ®@ Stud. his., H. ${ }^{a}$ mod., 39, n. 1 (2017), pp. 403-449 
MARÍA SEIJAS MONTERO Y LAURA RODICIO PEREIRA

LOS CABILDOS CATEDRALICIOS DE SANTIAGO Y ORENSE EN EL REINADO DE FELIPE V: ALGUNOS RESULTADOS

\section{BibliografíA}

Aranda Doncel, J.: «Los prebendados del cabildo catedralicio de Córdoba durante los siglos XVI y XVII: la provisión de la canonjía magistral», en Cortés PeÑA, A. L. y López Guadalupe Muñoz, M. L. (coords.): Estudios sobre Iglesia y sociedad en Andalucía en la Edad Moderna. Granada, 1999, pp. 137-152.

Aranda Doncel, J.: «Los canonicatos de oficio del cabildo catedralicio de Córdoba durante los siglos XVI y Xvir: la provisión de la canonjía lectoral», en CASTELlano, J. L. y López-Guadalupe Muñoz, M. L. (coords.): Homenaje a Antonio Domínguez Ortiz. Granada, 2008, pp. 55-80.

BARreiro Mallón, B.: «El clero de la diócesis de Santiago: estructuras y comportamientos (siglos XVI-XIX)», Compostellanum, 33, 1988, pp. 469-507.

Barreiro Mallón, B.: «La diócesis de Ourense en la Edad Moderna», en García Oro, J. (coord.): Historia de las diócesis españolas. Iglesias de Lugo, Mondoñedo-Ferrol y Orense, 15. Madrid, 2002, pp. 471-508.

Barreiro Mallón, B.: «La diócesis de Santiago en la época moderna», en García Oro, J. (coord.): Historia de las diócesis españolas. Iglesias de Santiago de Compostela y Tuy, 14. Madrid, 2002, pp. 177-215.

Barrio Gozalo, M.: «Perfil socioeconómico de una élite de poder, III: Los obispos del reino de Galicia (1600-1840)», Anthologica Annua, 32, 1985, pp. 11-107.

Barrio Gozalo, M.: «El clero secular en el reinado de Felipe V (1701-1746)», en Pereiras Iglesias, J. L. (coord.): Felipe V de Borbón 1701-1746: actas del Congreso de San Fernando (Cádiz) de 27 de noviembre a 1 de diciembre de 2000. Córdoba, 2002, pp. 343-378.

Barrio Gozalo, M.: «El clero en la España de Felipe V. Cambios y continuidades», en SERrano Martín, E. (coord.): Felipe $V$ y su tiempo: congreso internacional. Zaragoza, 2004, vol. 1, pp. 287-322.

Barrio Gozalo, M.: El clero en la España moderna. Córdoba, 2010.

Barriocanal López, Y.: Hospital, igrexa e pazos da abadía da Santísima Trinidade. Orense, 2003.

Barrios Manzano, M. P.: «Las funciones de chantre, sochantre y maestro de canto llano Den la catedral de Coria (Cáceres) 1590-1750», Cuadernos de arte de la Universidad de Granada, 26, 1995, pp. 73-82.

Bobillo Vázquez-Monjardín, M. Á.: «O Clero secular nunha cidade galega do século XVIII, o caso de Ourense», Historia nova IV: contribución dos Xoves Historiadores de Galicia. Santiago de Compostela, 1996, pp. 31-44.

Bobillo Vázquez-Monjardín, M. Á.: «Los Capitulares de la Catedral de Ourense ante la muerte en el siglo XVIII», Boletín de estudios del Seminario "Fontán-Sarmiento» de hagiografía, toponimia y onomástica de Galicia, 18, 1997, pp. 41-50.

Cal Pardo, E.: «Los Deanes de la Catedral de Mondoñedo», Estudios Mindonienses, 26, 2010, pp. 61-146.

Candel Crespo, F.: Deanes de la Catedral de Murcia (siglos XIII al XX). Murcia, 2005.

(C) Ediciones Universidad de Salamanca / ®@ Stud. his., H. ${ }^{a}$ mod., 39, n. 1 (2017), pp. 403-449 
MARÍA SEIJAS MONTERO Y LAURA RODICIO PEREIRA

LOS CABILDOS CATEDRALICIOS DE SANTIAGO Y ORENSE EN EL REINADO DE FELIPE V: ALGUNOS RESULTADOS

CÁnovas Botía, A.: Ange y decadencia de una institución eclesial: El cabildo catedral de Murcia en el siglo XVIII. Iglesia y sociedad. Murcia, 1994.

Carabias Torres, A. M.: «Catálogo de colegiales del Colegio Mayor de San Bartolomé (1700-1840)», Studia Historica. Historia Moderna, 9, 1991, pp. 43-88.

Carabias Torres, A. M.: «Salamanca, académica palanca hacia el poder», en Aranda PÉrez, F. J. (coord.): Letrados, juristas y burócratas en la España moderna. Cuenca, 2005, pp. 23-60.

Carabias Torres, A. M.: «Evolución histórica del colegio mayor. Del siglo XIv al XXI», REDEX. Revista de educación de Extremadura, 5, 2013, pp. 67-81.

Cebreiros Álvarez, E.: El municipio de Santiago de Compostela a finales del Antiguo Régimen (1759-1812). Santiago, 1999.

Coronas Vida, L. J.: «Los miembros del cabildo catedral de Jaén (1700-1737)», Chronica Nova, 15, 1986-1987, pp. 108-110.

Cortés Peña, A. L.: «La iglesia y el cambio dinástico», en Serrano Martín, E. (coord.): Felipe Vy su tiempo: congreso internacional. Zaragoza, 2004, vol. 1, pp. 991-1012.

DíAz IbáñEZ, J.: «Carrera eclesiástica e inquietudes religiosas de un clérigo castellano del siglo xv. Nuño Álvarez de Fuente Encalada, chantre de la Iglesia de Cuenca», En la España medieval, 36, 2013, pp. 263-326.

Díaz Rodríguez, A. J.: «Las casas del deán don Juan de Córdoba. Lujo y clientela en torno a un capitular del Renacimiento», Hispania Sacra, 61, 123, 2009, pp. 77-104.

Díaz Rodríguez, A. J.: "Cabildos catedralicios y clero capitular en el Antiguo Régimen: Estado de la cuestión», Revista de Historiografía, 13, 2010, pp. 82-99.

Díaz Rodríguez, A. J.: El clero catedralicio en la España moderna: los miembros del Cabildo de la Catedral de Córdoba (1475-1808). Murcia, 2012.

Duro PeÑA, E.: «Las antiguas Dignidades de la Catedral de Orense», Anuario de Estudios Medievales, 1, 1964, pp. 289-332.

Flórez, E.: España Sagrada, 1763, vol. 17.

González García, M. Á.: «El archivo y la biblioteca», La catedral de Ourense. La Coruña, 1997, pp. 470-479.

González García, M. Á.: «Don Alonso de Piña, Chantre de Ourense, Prior de Xunqueira de Ambía, mecenas y hombre de gobierno", Escritos dedicados a José María Fernández Catón. León, 2004, vol. 1, pp. 571-596.

González García-Paz, S.: O Colexio de San Clemente de Pasantes de Compostela. Santiago de Compostela, 1993.

González López, E.: El alba flor de lis. Galicia en los reinados de Felipe V, Luis I y Fernando VI. Sada, 1978.

Gonzalo Gozalo, Á.: El cabildo de la catedral de Burgos en el siglo XIX (1808-1902). Burgos, 1993, pp. 25-29.

Hernández Figueiredo, J. R.: «Actas del deán Bedoya durante la sede vacante de Orense (1841-1847)», Anthologica Annua, 55-56, 2008-2009, pp. 411-632.

(C) Ediciones Universidad de Salamanca / ®@ Stud. his., H. ${ }^{a}$ mod., 39, n. 1 (2017), pp. 403-449 
MARÍA SEIJAS MONTERO Y LAURA RODICIO PEREIRA

LOS CABILDOS CATEDRALICIOS DE SANTIAGO Y ORENSE EN EL REINADO DE FELIPE V: ALGUNOS RESULTADOS

Hervella Vázquez, J.: «La capilla de la Asunción o de Argiz en la Catedral de Ourense. La ascendencia orensana del primer marqués de San Saturnino», Porta da Aira, 3, 1990, pp. 93-128.

Iglesias Almeida, E.: «D. Lope García Sarmiento, un orensano Chantre de Tui», Porta da Aira, 3, 1990, pp. 219-226.

Iglesias Castelao, A.: «Análisis sociológico del cabildo compostelano a través de los expedientes de limpieza de sangre», Compostellanum, 41, 3 y 4, 2000, pp. 421-450.

Iglesias Ortega, A.: «Sociología capitular: el ejemplo del cabildo de la catedral de Santiago de Compostela en el siglo XvI», Obradoiro de Historia Moderna, 20, 2011, pp. 387-407.

IgLEsias ORTEGA, A.: «Élites eclesiásticas y sociedad en el siglo xvi: la extracción social de los capitulares compostelanos», Estudios humanísticos. Historia, 10, 2011, pp. 11-32.

Iglesias Ortega, A.: La Catedral de Santiago de Compostela y sus capitulares: funcionamiento y sociología de un cabildo en el siglo XVI. La Coruña, 2012.

Irigoyen López, A.: Entre el cielo y la tierra, entre la familia y la institución: el Cabildo de la Catedral de Murcia en el siglo XVII. Murcia, 2001.

Irigoyen López, A.: «Iglesia y sociedad en los primeros años del siglo XVIII según el obispo Belluga. Las relaciones “ad limina” de la diócesis de Cartagena (1705-1717)», en Serrano Martín, E. (coord.): Felipe V y su tiempo: congreso internacional. Zaragoza, 2004, vol. 1, pp. 415-428.

LAtorre Ciria, J. M.: Economía y religión. Las rentas de la catedral de Huesca y su distribución social (siglos XVI-XVII). Zaragoza-Huesca, Instituto Fernando el Católico-Instituto de Estudios Altoaragoneses, 1992.

Lop OTín, M. J.: El cabildo catedralicio de Toledo en el siglo XV. Aspectos institucionales y sociológicos. Madrid, 2003.

López DíAz, M.: «Élites locales y dinámicas de poder en la Galicia filipina: cambio dinástico y primeras tentativas reorganizadoras», en López DíAz, M. (ed.): Élites y poder en las monarquias ibéricas. Del siglo XVII al primer liberalismo. Madrid, 2013, pp. 99-128.

Morgado García, A. J.: «El alto clero gaditano durante el Antiguo Régimen (1600-1833)», Studia Historica. Historia Moderna, 16, 1997, pp. 223-256.

Morgado García, A. J.: «Discursos eclesiásticos en la España de Felipe V. Los manuales de confesores», en Pereiras Iglesias, J. L. (coord.): Felipe V de Borbón 1701-1746: actas del Congreso de San Fernando (Cádiz) de 27 de noviembre a 1 de diciembre de 2000. Córdoba, 2002, pp. 435-466.

Olivares Terol, M. J., «Las canonjías de oficio y oposición en el xvi murciano», Murgetana, 91, 1995, pp. 33-50.

Pérez Rodríguez, F. J.: «La diócesis de Orense: de la reforma gregoriana al Concilio de Trento», en García Oro, J. (coord.): Historia de las diócesis españolas. Madrid, 2002, vol. 15, pp. 441-451.

Pérez Rodríguez, F. J.: «Los cabildos catedralicios gallegos en la Edad Media (siglos XII-XIV)», Semata: Ciencias Sociais e Humanidades, 22, 2010, pp. 159-175.

Pro Ruiz, J.: «Las capellanías: familia, Iglesia y propiedad en el Antiguo Régimen», Hispania Sacra, 41, 84, 1989, pp. 585-602.

(C) Ediciones Universidad de Salamanca / ®@ Stud. his., H. ${ }^{a}$ mod., 39, n. 1 (2017), pp. 403-449 
MARÍA SEIJAS MONTERO Y LAURA RODICIO PEREIRA

LOS CABILDOS CATEDRALICIOS DE SANTIAGO Y ORENSE EN EL REINADO DE FELIPE V: ALGUNOS RESULTADOS

Quintana Andrés, P. C.: «El cabildo catedral de Canarias. Una élite socioeconómica e ideológica de ámbito regional», Revista de Historia Moderna: Anales de la Universidad de Alicante, 26, 2008, pp. 221-248.

Rey Castelao, O. y Barreiro Mallón, B.: «El clero regular mendicante en Galicia: evolución numérica, procedencia social y comportamientos de los franciscanos (ss. XVI-XIX)», Archivo Ibero-americano, 49, 195-196, 1989, pp. 459-490.

Rey Castelao, O.: «La renta del Voto de Santiago y las instituciones jacobeas», Compostellanum, 3-4, 1985, pp. 336-339.

Rey Ccastelao, O.: «El Voto de Santiago. Claves de un conflicto (I)», Compostellanum, 37:1-2, 1992, pp. 271-318.

Rey Castelao, O.: «Cistercienses y benedictinos en la Galicia moderna: evolución numérica y análisis social», Actas del Congreso Internacional sobre San Bernardo e o Císter en Galicia e Portugal, 2. Orense, 1992, vol. 2, pp. 309-324.

Rey Castelao, O.: «Mutaciones sociales en una sociedad inmutable. El Reino de Galicia en el reinado de Felipe V», en Serrano Martín, E. (coord.): Felipe V y su tiempo: congreso internacional. Zaragoza, 2004, vol. 1, pp. 343-374.

Rey Castelao, O.: «La financiación de la fábrica catedralicia compostelana, siglos XVII-XIX», Semata: Ciencias Sociais e Humanidades, 22, 2010, pp. 311-328.

Rodicio Pereira, L.: O cabido catedralicio de Ourense (1788-1808): Aproximación á Institución e aos seus componentes. Trabajo Fin de Máster, Universidad de Vigo, 2012.

Rodicio Pereira, L.: «Ser canónigo en Ourense a finales del siglo xvin», Diversarum Rerum, 8, 2013, pp. 135-158.

Sanz de la Higuera, F. J.: «El deán burgalés Calderón de la Barca (1704-1773). Un modelo de clérigo en el Setecientos», Historia y Genealogía, 4, 2014, pp. 7-30.

Seijas Montero, M.: «Las fundaciones pías de la catedral de Santiago: el ejemplo de Mencía de Andrade», Semata: Ciencias Sociais e Humanidades, 22, 2010, pp. 213-234.

Soria Mesa, E.: «Las capellanías en la Castilla Moderna: Familia y ascenso social», en Irigoyén López, A. y Pérez Ortiz, A. L. (coords.): Familia, transmisión y perpetuación (Siglos XVI-XIX). Murcia, 2002, pp. 135-150.

VÁzquez Lesmes, R.: Córdoba y su Cabildo catedralicio en la modernidad. Córdoba, 1987. Villacorta Rodríguez, T.: El Cabildo Catedral de León. León, 1974.

Zaragoza i Pascual, E.: «Abadologio del monasterio de San Salvador de Celanova (Siglos X-XIX)», Compostellanum, 45, 1-2, 2000, pp. 81-100.

(C) Ediciones Universidad de Salamanca / ®@ Stud. his., H. ${ }^{a}$ mod., 39, n. 1 (2017), pp. 403-449 
